\title{
INCIDENCIA DE LOS MOVIMIENTOS SOCIALES DE MUJERES EN LA ELABORACIÓN DE POLÍTICA PÚBLICA CON ENFOQUE DIFERENCIAL DE GÉNERO EN EL DEPARTAMENTO DEL META
}

\section{RESUMEN}

El Estado Social de Derecho en su más amplia concepción, debe establecer y garantizar en Colombia, el ejercicio democrático de sus ciudadanos a través de espacios de participación y deliberación que permitan la discusión en torno a la efectividad de derechos y prerrogativas. Por tanto, es precisa la inclusión de las mujeres como grupo determinado de la sociedad civil en la discusión de decisiones gubernamentales que las afecten.

Teniendo en cuenta lo anterior, con este informe se establecen los lineamientos y nivel de correspondencia entre la creación de políticas públicas y la participación activa de las mujeres en el Departamento del Meta, a partir de mecanismos reales de participación con enfoque diferencial.

Palabras Claves: Democracia, Políticas Públicas, Enfoque de Género, Participación Ciudadana, Movimientos Sociales. 


\begin{abstract}
The Social Rule of Law in the broadest sense must establish and guarantee in Colombia, the democratic exercise of its citizens through opportunities for participation and deliberation that allow discussion of the effectiveness of rights and prerogatives. Therefore, it is precisely the inclusion of women as a specific group of civil society in the discussion of governmental decisions that affect them.
\end{abstract}

Given the above, this report establishes guidelines and levels of correspondence between the creation of public policies and active participation of women in the Department of Meta, based on real mechanisms of participation set by a differential approach.

Keywords: Democracy, Public Policy, Gender, Civic Participation, Social Movements. 


\section{Tabla de Contenido}

Pág.

\section{Introducción}

$\begin{array}{ll}\text { Capítulo 1. Democracia Participativa } & 7\end{array}$

1.1. Generalidades del Concepto de Democracia $\quad 7$

1.2. Democracia Deliberativa y Participativa 17

1.3. De la Participación en la constitución de 1991 - El caso práctico en el Departamento del Meta $\quad 30$

1.3.1. Constitución Política de Colombia y su modelo de participación $\quad 30$

1.3.2. Mecanismos de participación 36

1.3.2.1. Ley 134 de 1994

1.3.2. 2. Sentencia C-150 de 2015

Capítulo 2. Sociedad Civil y Movimientos Sociales 43

2.1. Generalidades de los Movimientos Sociales 43

2.2. Movimientos Sociales desde la Perspectiva de las Mujeres 48

2.3. Impacto de los Movimientos Sociales de las mujeres en la Elaboración de Políticas

Publicas $\quad 55$

Capítulo 3. Política Pública $\quad 63$

3.1. Generalidades de la Política Pública $\quad 63$

3.2. Instrumentos Nacionales e Internacionales de Política Pública 68

3.2.1. Instrumentos Internacionales 69

3.2.2. Ámbito América Latina $\quad 72$

3.2.3. Ámbito Nacional 76

3.3. Aplicación y verificación de dichos instrumentos en el Departamento del Meta 81

$\begin{array}{lr}\text { Conclusiones } & 86\end{array}$

$\begin{array}{ll}\text { Bibliografía } & 92\end{array}$ 


\section{TABLA DE GRÁFICOS}

Pág.

Gráfico 1. Partidos político y los movimientos sociales

Gráficos 2. Representación de Hombres y Mujeres en Asambleas Legislativas en Latinoamérica.

Gráfico 3. Matriz de Análisis en el Diseño de Políticas Públicas.

Gráfico 4. Comparación de los acuerdos del Consenso de Brasilia y los ejes de la política de Equidad de Género para las mujeres en Colombia.. 


\section{INTRODUCCIÓN}

Por muchos años, las mujeres en todos los lugares del mundo han luchado por lograr equidad y por obtener y ver garantizados sus derechos humanos. Aunque producto de sus luchas han obtenido un papel muy importante en diversos campos de la sociedad y del Estado, aun hoy no son reconocidas en completas condiciones de igualdad y equidad. En Colombia por ejemplo, muchas mujeres que viven en la periferia siguen sufriendo las inclemencias de ser relegadas a las funciones domésticas y a la violencia por parte de los hombres que todavía viven en un país machista que pareciera no querer dejar de existir.

Es por ello, que las mujeres al conformar un grupo minoritario tradicionalmente excluido, deben contar con herramientas de participación e incidencia en la elaboración de políticas públicas, teniendo en cuenta que el Estado Social de Derecho establece como uno de sus principales ejes, la democracia participativa a fin de conseguir la debida reciprocidad y correspondencia entre la ciudadanía y las instancias gubernamentales.

Si bien es cierto, esas herramientas para la participación activa de las mujeres están constitucional y legalmente establecidos en Colombia, también lo es, que no han sido eficaces, puesto que la implementación en nuestro país de un sistema vertical de política pública, ha hecho que la gran mayoría de políticas públicas existentes en favor de las mujeres, hayan obviado las experiencias y conocimientos de organizaciones, redes y movimientos existentes en el ámbito regional, departamental y local. En otras palabras, el esquema vertical de construcción de política pública que atenta directamente contra el principio constitucional de descentralización administrativa y territorial, ha condenado a las mujeres de la periferia geográfica de nuestro país a la invisibilidad, pues los contenidos sustantivos y adjetivos que trazan las políticas públicas existentes, se han elaborado desde 
una lógica sectorial que avanza en dirección de lo nacional, hacia lo regional, departamental y local.

Esto ha generado, que las problemáticas y necesidades particulares del grupo poblacional de mujeres del Departamento del Meta, no hayan sido abordadas puntualmente por las políticas públicas existentes desde lo nacional y departamental, puesto que se han construido desde la mirada de asomo del sector central, situación que a la postre, no solo ha impedido la materialización de la democracia participativa en esta región oriental del país en gracia a que la participación ciudadana desde lo que implica la toma de decisiones, la protección y materialización de los derecho fundamentales, y, la intervención real de los ciudadanos en tales deliberaciones sencillamente no se ha realizado-, sino que también ha mostrado la ineficacia de la acción gubernamental para la atención debida de este sufrido grupo social.

Por tanto, es indispensable la participación activa de las mujeres para su inclusión directa en la planeación, elaboración y ejecución de las políticas públicas en el Departamento del Meta con el fin de que se incluyan en tales políticas, tanto sus experiencias, conocimientos y proyectos, como también se consiga la realización de sus derechos y sus mecanismos de defensa. Ello permitirá que el contexto (histórico, geográfico, social, cultural, político, económico), las vivencias, los conocimientos y las experiencias históricas de vida de las mujeres, sean uno de los ejes transversales en la planeación, elaboración y ejecución de la política pública, para que en conjunto con el concepto de participación, deje de ser una concepción netamente teórica y se conjugue como una efectiva acción del Estado, que tenga un impacto relevante y positivo para la región y el departamento. 


\section{CAPÍTULO 1 \\ DEMOCRACIA PARTICIPATIVA}

\subsection{Generalidades del concepto de Democracia.}

Para realizar un proceso investigativo y práctico en torno a los mecanismo de participación reales con los que cuentan los movimientos sociales de mujeres en el Departamento del Meta para su participación real y efectiva en la elaboración de políticas públicas que sean de su interés particular, es preciso analizar en primer lugar los orígenes y el concepto general del concepto de democracia, y, posteriormente abordar propiamente el desarrollo de lo que se ha concebido como la democracia participativa y deliberativa como fundamentos y orígenes de la intervención ciudadana a través de los movimientos sociales en las decisiones de los gobiernos Nacionales, Departamentales o Locales..

Definir la democracia en términos prácticos resulta como lo dice el maestro Giovanni Sartori (1993, pág. 4 y 5) una tarea difícil, puesto que la realidad de los actuales sistemas democráticos en diferentes latitudes, entre ellos nuestro sistema político Colombiano, demuestran que la concepción ideal de dicha forma de gobierno parece imposible de consumarse. Así, son evidentes las democracias donde las mayorías son manipuladas por unos pocos que por tradición han ostentado el poder; otras, donde quienes asumen el gobierno se han autoproclamado como los caudillos reivindicadores de los menos favorecidos; y también aquellas donde el rígido sistema de contrapesos entre los poderes del poder público, hacen muchas veces utópico la puesta en marcha de iniciativas que favorezcan el desarrollo de los Estados y por ende la satisfacción - como el caso práctico motivo de análisis - de derechos y garantías a sus asociados.

En el mismo sentido, el destacado profesor italiano Sartori, señala que lo más sencillo entonces para entender la democracia sería explicar lo que etimológicamente es: "La 
palabra significa, literalmente, poder (Kratos) del pueblo (Demos)” (Sartori, 1993, pág. 3); sin embargo, definirlo es más complejo, pues considera que la democracia "desde siempre ha indicado una entidad política, una forma de Estado y de gobierno, y así ha permanecido como la acepción primaria del término" (Sartori, 1993, pág. 5). Particularmente y dado el tema objeto de investigación, Sartori define un aspecto de la Democracia social que se caracteriza especialmente según lo determina Tocqueville en la sociedad de los Estados Unidos en 1831 y que se caracterizaba por igualdad de condiciones y guiada por un "espíritu igualitario"; toda vez que consideraba que "la democracia no es aquí lo contrario a régimen opresor, de tiranía, sino de "aristocracia": una estructura social horizontal en lugar de una estructura social vertical”. (Sartori, 1993, pág. 5)

Es decir, desde lo que pretende el análisis del caso práctico en el Departamento del Meta de la participación ciudadana como elemento fundamental de la Democracia en su acepción mas general, se hace necesario rescatar las relaciones de carácter horizontal entre los ciudadanos de un sistema democrático como el Colombiano y sus representantes entendidos como el Estado, en pro de la consecución de prerrogativas logradas desde la comunicación real y efectiva, conseguida a través de mecanismos de participación constitucional y legalmente establecidos bajo la concepción de la igualdad y justicia que caracteriza nuestro Estado Social de Derecho actual.

Para el profesor Ayala Sánchez la forma de Gobierno Democrática consideraba como "práctica necesaria el sometimiento de las decisiones de gobierno a la voluntad del pueblo, por lo que la participación popular en esta materia era directa. Cómo es de imaginarse, en el ejercicio de este tipo de democracia no siempre se contaba con el consenso total de la sociedad, por lo que se imponía la voluntad de la mayoría” (Ayala Sánchez, 2012, pág. 4); este es uno de los problemas o disensos más comunes y foco de discusión dentro del modelo de democracia liberal actual en la medida en que no siempre las decisiones van a contar con la aprobación de todo el pueblo, y además siempre y en principio las mayorías 
terminan decidiendo por los grupos minoritarios y por lo general tradicionalmente excluidos. Situación que genera la creación y organización de los ciudadanos a través de grupos sociales y civiles que representen su interés y genere la necesidad de la comunicación directa entre el Estado, los ciudadanos y sus decisiones, teniendo en cuenta sus posibles efectos en estos colectivos.

En ese orden de ideas explica el mismo autor, que ese concepto de Democracia Liberal que actualmente conocemos y se evidencia en nuestro sistema Colombiano particularmente desde 1991 tenía en particular "la defensa del individuo ante el Estado y...crear reglas y contrapesos para que el poder de los gobernantes no atropellara los derechos inalienables de los ciudadanos" (Ayala Sánchez, 2012, pág. 5). Parte de tales reglas, se manifiestan a través de las herramientas y alternativas en materia de participación con las cuales cuentan los ciudadanos para hacer efectivos sus derechos y garantías frente a sus representantes a quienes han elegido de manera directa, lo que conlleva a que hoy en día está ligada directamente la Democracia con el concepto de la Gobernabilidad.

Uno de los autores más representativos de la doctrina de la democracia liberal, caracterizada por la defensa del individuo fue John Locke y a quien se reconoce como el padre del liberalismo; para el mismo autor, Locke “...defendía la idea de que todas las personas tienen la habilidad de razonar y por lo tanto pueden gobernarse a sí mismas y ver por el bien común de la sociedad" a lo que habría que agregar, y de sus propios intereses a través de la participación ciudadana activa, real y efectiva, en la medida en que consideraba que los gobiernos se conformaban para "proteger la vida, el derecho a la libertad y a la propiedad privada.” (Ayala Sánchez, 2012, pág. 5)

Dicho pensamiento de Locke, analiza Ayala (2012) desde el individuo como sujeto de protección, junto con la teoría de la división de poderes de Montesquieu y la teoría de la soberanía popular de Rousseau como el derecho que tiene los ciudadanos a gobernarse por 
sí mismos para representar el interés de todos los ciudadanos, fueron las características o teorías que permearon las constituciones de América y Europa en los siglos XVIII Y XIX. En esos términos del denominado espíritu igualitario, ya no solo se hace referencia al criterio de decisión electoral, sino que también al de decisión que recae sobre el pueblo, siendo este último el más extenso y que para efectos del presente análisis llama más la atención, en la medida en que es necesario que a través de la participación en las actuaciones no solo legislativas, sino desde el ejecutivo y sus políticas ( en el caso Departamental ) puedan incidir directamente en la toma de decisiones, toda vez que lo que está en juego son los interés de una comunidad en particular, como el caso de las mujeres como grupo poblacional tradicionalmente excluido.

Robert Dahl (2004) explica que el filósofo pragmatista norteamericano más importante de la primera parte del siglo XX y que más estudio la democracia, y en favor de ellas se deriva en:

Su fe democrática se cimentaba en que más que una forma de gobierno, un conjunto de instituciones o de garantías legales, la democracia era una forma de vida necesaria para que el ser humano pudiera ejercitar sus potencialidades de enjuiciar racionalmente y de deliberar públicamente. En otras palabras, Dewey cree que desde la praxis cotidiana el ser humano esta vocacionado democráticamente, puesto que la experiencia de vida, los conflictos y los problemas que se generan en el día a día dentro de una vida en comunidad, necesariamente deben tramitarse a través del debate público, la persuasión racional, la libre comunicación y la misma reconstrucción de experiencias de todos los ciudadanos. (Pág. 41 - 42)

Concepto totalmente acertado y de absoluto desarrollo en el caso objeto de estudio, toda vez que exalta la necesidad y la importancia que dentro de las relaciones Estado y sus ciudadanos, requieren y como se explicara adelante con el concepto de democracia 
deliberativa y participativa propuesta por Habermas y Rawls, requieren de la deliberación de la opinión publica y la comunicación real y efectiva entre los ciudadanos y sus representantes en asuntos que les competen a sus asociados.

En línea con lo analizado Dahl considera que el autor Dewey "se inscribe en una idea moral de democracia", que concibe al individuo en comunidad siendo el "único lugar en el cual, el mismo individuo encuentra los espacios de debate, discusión y persuasión." Situación que considera el autor "solo se logra gracias a la educación de todos los ciudadanos y de ahí la importancia que da el autor a la educación y a la escuela para la consolidación de una verdadera sociedad democrática: "Gran parte de la educación actual fracasa porque descuida el principio fundamental de la escuela como una forma de vida en comunidad". (Dahl, 2004 pág. 43 y 44)

Ahora bien, las concepciones expuestas sobre la democracia, conducen a fijar la atención en la praxis de quien ostenta el poder democrático como tal: el Pueblo. En el sistema democrático de gobierno, el Pueblo es entendido como aquella "entidad" sobre la cual recae la soberanía y quien en términos de decisión, resuelve conforme a la regla del principio mayoritario absoluto, de manera tal que “...el pueblo que decide en términos de principio mayoritario absoluto es, las más de las veces, un cuerpo que representa al pueblo, y que refleja en gran parte a la mayoría que lo elige" (Sartori, 1993, pág. 16). Esto implica que en la dinámica democrática, el Pueblo se divida entre quienes han ganado el poder por hacerse ver como la mayoría y aquellos que lo han perdido porque no consiguieron dicha supremacía, situación que a todas luces, resulta deplorable porque degenera en una reducción de la minorías prácticamente a la impotencia.

La misma naturaleza de la democracia aprueba en términos de Sartori, el disenso en la medida en que "al confiar el gobierno a la mayoría tutelan el derecho de hacerle oposición” (Sartori, 1993, pág. 16) y no solo desde el punto de vista de la simple elección, sino 
también, en la toma de decisiones que afecten potencialmente los derechos y el papel de todos los habitantes como personas y ciudadanos.

Adela Cortina mujer creyente y Kantiana, en un texto titulado "Las raíces éticas de la democracia" enseña la democracia emotiva, es decir, aquella en la que las mayorías se forman por manipulación de los sentimientos de los ciudadanos (Cortina, 2010). Según la autora, las élites políticas manipulan los sentimientos y emociones de los electores con el fin de conseguir sus votos entendiendo la política como el arte de la conquista y conservación del poder, un procedimiento que en la actualidad democrática ha resultado muy eficaz. También explica lo que ella denomina democracia agregativa, es decir, aquella que reconoce que en una sociedad pluralista los desacuerdos son inevitables pero hay consciencia a la vez, que es necesario llegar a ciertos acuerdos por la mayoría, primero por la unanimidad, pero esta resulta muy conservadora y demorada. Por tanto, afirma que es inevitable recurrir a la mayoría que siempre es mejor que la minoría, para forjar la suma de intereses individuales y satisfacer los de la mayoría.

En ese sentido y entendiendo la democracia como el mandato de las mayorías sobre las minorías, J. J. Rousseau explica que no es lo mismo la voluntad mayoritaria que la voluntad general, teniendo en cuenta, que en el Contrato Social toda persona debe obrar siempre movida por un interés, que si es compatible con el de los demás se denomina interés común y si es incompatible en esa misma perspectiva, es interés individual. Así para Rousseau de lo que se trata es que en la democracia triunfe el interés común, por lo cual, los intereses comunes se suman y los intereses individuales se restan. Además, sostiene que el Contrato Social es adverso a los Partidos Políticos porque según él, aquellos reúnen intereses particulares para hacerlos mayoritarios, de modo que un interés particular mayoritario que triunfa es distinto al interés común. Para el autor, el partido político se presenta con un nombre atractivo para no delatar sus intereses y luego empieza a seducir a los electores con promesas y dádivas; de esta manera, lo que triunfa entonces es la voluntad de los autores 
del partido avalada por una mayoría que no es la voluntad general, sino la mayoritaria, porque aquella coincide con un interés común y en esta realidad no hay interés común. (Dahl, 2004 pág. 26,27,28)

Situación que los movimientos sociales a través de sus luchas, pretenden reivindicar las garantías y derechos que en ocasiones y a través de decisiones mayoritarias en los términos expuestos que no coincide con la realidad y los intereses comunes de la ciudadanía y particularmente como se ha venido exponiendo, generalmente en grupos excluidos y sin poco o nulo poder de participación, no solo en términos electorales sino en la incidencia en la toma de decisiones en pro de su propio bienestar en todas las esferas gubernamentales como en el caso práctico Colombiano, pero de manera particular y objeto de análisis en el Departamento del Meta frente a la elaboración de la política pública de las mujeres.

Robert Dahl (2004) en su análisis de democracia y analizando a Aristóteles, quien plantea las características básicas de la democracia, señala como mínimo los siguientes rasgos:

La democracia ideal debería exhibir los siguientes rasgos: Participación efectiva. Antes de adoptar o rechazar una política, los miembros del demos tienen la oportunidad de dar a conocer a los demás miembros sus opiniones al respecto. Igualdad de votos. Los miembros del demos tienen la oportunidad de votar a favor o en contra de una política, y todos los votos se computan igual. Electorado informado. Los miembros del demos tienen la oportunidad, dentro de un período razonable, de aprender acerca de la política y sobre las posibles políticas alternativas y sus consecuencias probables. Control ciudadano del programa de acción. El demos, pura y exclusivamente, decide qué asuntos se incluyen en la agenda de la toma de decisiones y cómo han de incluirse allí. De este modo, el proceso democrático es "abierto", en el sentido que el demos puede cambiar las 
políticas de la asociación en cualquier momento. Inclusión. Cada uno de los miembros del demos tiene derecho a participar en la asociación según hemos expuesto. Derechos fundamentales. Cada uno de los rasgos necesarios de la democracia ideal prescribe un derecho que constituye en sí un rasgo necesario. La democracia de la democracia ideal: así, cada miembro del demos tiene el derecho de comunicarse con otros; el derecho de que su voto se compute igual que los votos de los demás; el derecho de recabar información; el derecho de participar en idéntica condición que los otros miembros; y el derecho, junto con otros miembros, de ejercer el control de la agenda. Por ende, la democracia es más que un mero procedimiento político; necesariamente, también es un sistema de derechos fundamentales. (Pág. 48-49)

Estas características que exigen la participación ciudadana desde lo que implica la toma de decisiones, y, la protección y materialización de los derecho fundamentales, pretenden también, que dentro del ejercicio democrático se garantice la intervención real de los ciudadanos en tales deliberaciones. Por ello, se resalta que la participación en la democracia no es únicamente la manifestación de la voluntad a través del ejercicio de los derechos políticos y la elección de los representantes del pueblo, sino es también, la participación activa de los ciudadanos de los temas que afecten a toda la población.

En estos términos, Aristóteles entendía la democracia ideal, como aquella que velaba por la participación en lo que él denominaba la agenda, es decir, la participación que se realiza desde el control político y ciudadano que ejerce el Pueblo en ejercicio de su poder como constituyente primario y soberano; dicha agenda, se encarna actualmente en las demandas sociales que dadas las circunstancias especialmente en materia de vulneración de derechos, ha llevado a que el Pueblo exija ya no solo la participación a través de la elección de sus representantes, sino la contribución e intervención 
directamente en la elaboración y ejecución de las políticas y decisiones que les competen, a través de diferentes mecanismos de participación que realmente reflejen las demandas particulares de aquellos grupos sociales que requieran y ameriten una determinada decisión o política de carácter especial y particular en el Departamento del Meta y el grupo poblacional particular de las Mujeres y su participación activa en la tomas de decisiones. .

En esa perspectiva y para efectos de lograr que los conceptos de la democracia se realicen a través de la participación real y efectiva del Pueblo en la toma de decisiones de carácter general o de afectación para un grupo en particular, Dahl señala que es preciso contar dentro del Estado con las siguientes instituciones o herramientas de participación y comunicación entre los representantes y los representados:

Elecciones libres, limpias y periódicas. Los ciudadanos pueden participar en dichas elecciones tanto en calidad de votantes como de candidatos (si bien pueden imponerse restricciones en términos de edad y residencia). Libertad de expresión. Los ciudadanos pueden expresarse en público sobre una amplia gama de temas políticamente relevantes sin temor al castigo. Fuentes de información independientes. Existen fuentes de información política que no se hallan bajo control del gobierno ni de grupo único alguno y cuyos derechos a publicar información o difundirla de otro modo están protegidos por ley; es más, todos los ciudadanos tienen derecho a buscar y emplear dichas fuentes de información. ( 2004, págs. 46-47)

En la actualidad, los ciudadanos se han visto en la necesidad no solo de participar en el ejercicio democrático a través de la elección de sus representantes, sino también, a través de la asociación o agrupación con otros ciudadanos que se identifican frente a 
necesidades o garantías que consideran deber ser satisfechas por el gobierno. Esa es otra de las características primordiales para la manifestación de la democracia según la cual:

Los ciudadanos tienen el derecho de formar organizaciones políticas independientes y participar en ellas, incluidos los partidos y los grupos de interés. Instituciones como estas se desarrollaron en Europa y Estados Unidos, en diversas circunstancias políticas e históricas, y los impulsos que las promovieron no siempre fueron en sí democráticos. Pero a medida que fueron desarrollándose, se hizo cada vez más evidente que eran necesarias para lograr un nivel satisfactorio de democracia en cualquier asociación política del tamaño de un Estado-nación. La relación entre estas instituciones y las características de una democracia ideal que se realiza a través de aquellas puede resumirse de la siguiente manera. En una asociación del tamaño de un Estado-nación, la representación resulta necesaria para la participación efectiva y el control ciudadano del programa de acción; las elecciones libres, limpias y periódicas también son necesarias para la participación efectiva y la igualdad de votos; y la libertad de expresión, las fuentes independientes de información y la libertad de asociación son todas necesarias para una participación efectiva, un electorado informado y el control ciudadano del programa de acción. (Dahl, 2004, págs. 47-48)

Para la existencia de una democracia real es necesario entonces, que converjan la eficacia, la legitimidad y la estabilidad del poder político, a fin de que las demandas del Pueblo se cumplan debida y cumplidamente. Estos tres elementos fundamentales, relacionan estrechamente los conceptos de democracia y gobernabilidad, pues a través de ellos ocurre un estado de equilibrio dinámico entre las demandas sociales y la capacidad de respuesta gubernamental; sin embargo, en la medida que dicho precepto no 
se materialice obliga a que los ciudadanos organizados a través sus organizaciones exijan la participación directa en la toma de decisiones cuando sus representantes no lo hacen correctamente y es lo que hace posible que tomen más fuerza los conceptos de democracia participativa y deliberativa.

\subsection{Democracia Deliberativa y Participativa.}

El modelo democrático participativo y deliberativo, en términos generales propende por el diálogo constante y la toma de decisiones conjuntas entre la ciudadanía y sus representantes - Estado- en los asuntos que la afectan directamente, y especialmente cuando se trata de derechos y prerrogativas. Para el caso objeto de estudio, las mujeres han sido un grupo que a lo largo de la historia lucha por el reconocimiento de garantías; toda vez que tradicionalmente se ha considerado un grupo minoritario y excluidos socialmente.

En esa medida, Jürgen Habermas (1998) establece que los derechos de participación política y comunicación como parte de los derechos fundamentales de los ciudadanos, garantizan no la libertad respecto de coerciones externas, sino la posibilidad de participación en una praxis común, cuyo ejercicio es lo que permite a los ciudadanos convertirse en aquellos que quieren ser, en autores políticamente autónomos de una comunidad de libres e iguales; de allí que la justificación de la existencia del Estado no radica primariamente en la protección de iguales derechos subjetivos, sino en la garantía que ofrece de un proceso de formación de la opinión y la voluntad, en el que sujetos iguales y libres se entienden acerca de qué objetivos y normas son en interés común de todos.

Esta asimilación de la formación de la opinión y de la voluntad política al auto entendimiento ético-político como lo explica Habermas (1998.Pág. 430-432), no se 
compadece con la función del proceso de producción legislativa, en el que desemboca, pues en las leyes entran, ciertamente, también elementos teleológicos, pero estos no se agotan en fines y objetivos colectivos. Así, conforme a su estructura, las leyes vienen determinadas por la pregunta ¿qué normas quieren los ciudadanos para regular su convivencia? esta definición genera algún tipo de discusión al intentar poner de acuerdo y entender cómo cada ciudadano quiere entenderse como miembro de un determinado Estado, y teniendo en cuenta que dichos "discursos de auto entendimiento" es decir a través de los cuales se expresa ese ciudadano, van a estar "subordinadas a cuestiones morales y guardan relación con cuestiones pragmáticas", para ello tal como acontece en los Estados Sociales de Derecho existen una serie de principios y valores axiomáticos contenidos en la constitución que permitirán entender en términos de Habermas " como puede regularse una materia en interés de todos por igual.

En ese sentido se aboga, no solo desde la expedición de leyes en sentido formal como modelo de representación de la ciudadanía, sino a través de participación más real y cercana a las realidad locales y propias de cada entorno cómo las políticas públicas; se quiere entonces la democracia deliberativa y participativa de la ciudadanía en situaciones particulares y en contextos sociales, económicos y culturales propios de los grupos o movimientos sociales que lo reclamen para sí; en la medida en que la democracia no se agota con la representación, es necesario que las decisiones que afectan a un colectivo con identidad propia participen de manera activa en la toma de decisiones que impactarán directamente su grupo.

En ese orden de ideas, John Rawls (1996) en la teoría de la justicia, hace indispensable el concepto de la razón pública que definirá como:

“característica de un pueblo democrático-y como - la razón de sus ciudadanos de quienes comparten una posición de igual ciudadanía. El objeto de su razón es el bien 
público: aquello que la concepción política de la justicia exige a la estructura institucional básica de la sociedad y a los propósitos y fines que las instituciones han de servir". ( Pág. 248)

Aunque tal como lo describe, si bien se trata de una concepción ideal de la ciudadanía en un régimen Constitucional Democrático presenta como podrían ser las cosas si la gente actuará de determinada manera y como la sociedad justa y bien ordenada los incitaría a ser. Esto lo entiende Rawls como lo que es posible pero aclara que quizá nunca llegue a ocurrir pero que al final no lo hace menos fundamental.

Guillermo Hoyos ( 1999. Pág. 208-209) en estudio a los autores citados, considera que, la teoría discursiva de la política y del derecho abre desde un principio la sociedad civil y lo público a la participación democrática, en búsqueda tanto de comprensión de la complejidad de la sociedad, como de acuerdos mínimos que posibiliten el Estado social de derecho. Situación realizada con la constituyente de 1991 que materializó y aterrizó el concepto de democracia más allá de la representación a través del ejercicio democrático del voto.

En línea con los planteamientos esbozados, en un modelo democrático como el Colombiano, en términos de Pierre Rosanvallon (2007. Pág.115) se han de buscar formas de participación de los ciudadanos en las decisiones que les conciernen, como uno de los mayores rasgos de la evolución reciente de la democracia; para ello, recurre al término de Democracia Participativa, pues es el que mejor describe ese intento de la sociedad por brindar esas garantías participativas, particularmente a los grupos que representan a la sociedad civil en aras del cumplimiento de una demanda social, o de vulneración y no reconocimiento de los derechos fundamentales. 
En términos de Rosanvallon (2007) se considera que las diferentes organizaciones civiles y políticas pueden participar como representantes de los diferentes grupos y minorías del Estado y ello ha de funcionar como una forma de consolidar la democracia, en la medida en que están organizadas, y son quienes que han de alertar a la opinión pública frente a determinada situación, pero con argumentos sólidos. El autor propone para ello que se desarrollen agencias ciudadanas de calificación para evaluar las acciones de ciertos organismos públicos. Se podría construir también observatorios ciudadanos para llamar la atención de la opinión pública sobre problemas emergentes o evoluciones preocupantes.

Concluye el autor que "hacer más visible la política debe consistir ante todo en el recordatorio permanente de la tarea que se trata de cumplir: constituir un pueblo inhallable en comunidad política viva. La simbolización es reflexión colectiva, relación con la decisión reafirmada de escribir una historia común; es el relato sensible y grave de los fracasos y las esperanzas que tejen esa empresa, es historia y memoria de la lucha de los hombres y las mujeres por tratar de instituir a pesar de todas las dificultades una sociedad de iguales". (Pág. 284-286)

Otra propuesta que ha de servir como fundamento o respuesta a la intervención de los ciudadanos y la democracia, es la democracia disputatoria de Pettit quien afirma que " Las autoridades ejercerán un poder arbitrario, si las decisiones que toman pueden fundarse en sus intereses personales o banderizos, o en su interpretaciones personales o banderizas de las obligaciones que entraña ser legislador, administrador o juez". Más peligroso aún, si los grupos organizados no han sido tenidos en cuenta a la hora de tomar la decisión, bien indica el autor que las decisiones de carácter público no ha de ser impuesta arbitrariamente sino que "tiene que proceder de tal modo, que podamos identificarnos con ella y hacerla nuestra: que podamos ver en ella promovidos nuestros intereses y respetadas nuestras interpretaciones". (Pág. 240 -241) 
Nancy Fraser (1997) considera que:

"La idea de una esfera pública va más allá de esa esfera pública burguesa a la que Habermas idealiza, la idea de esfera pública corresponde a un cuerpo de personas privadas reunidas para discutir asuntos de interés público o común. Esta idea adquirió fuerza y realidad en la Europa moderna temprana...interacción discursiva. Aquí, la esfera pública connotaba un ideal de discusión racional irrestricta sobre los asuntos públicos. Esta discusión debía ser abierta y estar al alcance de todos.” (Pág. 100-103)

En ese sentido, el problema está en que Habermas dejó de examinar otras esferas públicas no liberales, no burguesas. Fraser demuestra que esa esfera pública era completamente discriminatoria y que pese a guardar el derecho a estar al alcance de todos y ser abierta en la realidad no lo era. Esta esfera pública en las sociedades estratificadas "genera presiones informales que marginan las contribuciones de los miembros de los grupos subordinados, tanto en los contextos de la vida cotidiana, como en las esferas públicas oficiales...la economía de esa esfera pública amplía en lugar de mitigar tales presiones. En esta esfera pública, los medios que constituyen el soporte material para la circulación de las ideas son propiedad privada y operan con ánimo de lucro. Por consiguiente, los grupos socialmente subordinados carecen por lo general de un acceso igual a los medios materiales que permiten la igual participación”. (Fraser, 1997. Pág. 102-103)

De tal forma, la afirmación en términos de la opinión y esfera de lo público de "que la sociedad civil puede en determinadas circunstancias cobrar influencia en el espacio de la opinión pública, operar a través de opiniones propias sobre el complejo parlamentario (y sobre los tribunales) y obligar al sistema político a retornar a asentarse sobre la circulación oficial del poder" (Habermas, 2005, pág. 454), sirve para el caso de organizaciones sociales representadas como sociedad civil, que pueden influir en la toma de decisiones frente a la 
elaboración de políticas públicas y en las medidas que deben adoptarse a través de dichos instrumentos gubernamentales en la esfera nacional, regional, departamental o local.

Las organizaciones sociales en ese sentido, cobran relieve e importancia porque demandan necesidades y reconocimiento que hacen visibles a través de sus reclamos de carácter administrativo y judicial, pero los resultados de dicho accionar generalmente no son los esperados porque "...las agrupaciones de la sociedad civil son, ciertamente, sensibles a los problemas, pero las señales que emiten y los impulsos que dan son por lo general demasiado débiles como para provocar a corto plazo procesos de aprendizaje en el sistema político o para reorientar los procesos de toma de decisiones" (Habermas, 2005, pág. 457).

Este tipo de grupos y actores de carácter civil como las que requieren de la participación activa e incidencia en la elaboración de las políticas públicas en aras de la defensa y salvaguarda de los derechos humanos de las mujeres en el Departamento del Meta han sido denominadas por Habermas como "actores que deben empezar produciendo sus propias características identificadoras..."; resalta con especial claridad en el caso de los movimientos sociales, que primero "han de recorrer una fase de autoidentificación y autolegitimación..... han de desarrollar una identity-politics de tipo autorreferencial, han de asegurarse una y otra vez su propia identidad" (Habermas, 2005, págs. 456-457); en un país como Colombia, este propósito se hace más complejo, dadas las circunstancias de tales grupos minoritarios, que poco o nada son escuchados, además de las presiones y las amenazas a las que en ocasiones están expuestos, quizás por algunos intereses particulares, a los que no les conviene que tales derechos sean efectivamente protegidos, dadas las dinámicas que se llevan a cabo en el marco de un conflicto armado interno.

El problema está entonces, en la imposibilidad de que las ideas y propuestas de los movimientos y grupos sociales lleguen de manera efectiva a las instancias o esferas de las instituciones públicas que tienen poder de decisión y de defensa de los derechos humanos 
de todos los miembros de la sociedad civil. Además, porque son dichos movimientos los que conocen a fondo como en el caso de las mujeres en el Departamento del Meta la verdadera problemática social pues "las estructuras de comunicación del espacio de la opinión pública están ligadas con los ámbitos de la vida privada de modo que la periferia que es la sociedad civil, frente a los centros de la política, posee la ventaja de tener una mayor sensibilidad para la percepción e identificación de nuevos problemas". (Habermas, 2005, pág. 463). Para el caso puntual de los movimientos de mujeres en el Departamento del Meta, su visibilización dependerá de la materialización de mecanismos de participación que no solo promuevan el diálogo, sino que efectivamente hagan posible que las demandas por ellas impetradas, sean parte de la opinión pública y de lo que ha denominado Habermas la agenda formal, que para el asunto particular, corresponde a la política pública del Departamento del Meta.

En términos de Habermas y según lo establecido en nuestra Constitución Política a partir de 1991, teniendo en cuenta que el proceso Constituyente Colombiano de 1991 fue considerado por muchos como lo más semejante a la realización de un consenso y motivo constante de gran debate entre las diferentes fuerzas políticas, sociales y culturales con las cuales contaba en su momento nuestro país, se introdujo la cláusula de Estado Social de Derecho (T406, 1992) y desde el estudio que Habermas hace al republicanismo es la participación política y comunicación (Organizaciones Civiles ) quienes:

"garantizan, no la libertad respecto de coerciones externas sino la posibilidad de participación en una praxis común, cuyo ejercicio es lo que permite a los ciudadanos convertirse en aquellos que quieren ser, en autores políticamente autónomos de una comunidad de libres e iguales... de allí que la justificación de la existencia del estado no radica primariamente en la protección de iguales derechos subjetivos, sino en la garantía que ofrece de un proceso de formación de la opinión y la voluntad, en 
el que sujetos iguales y libres se entienden acerca de qué objetivos y normas son en interés común de todos“ (Habermas, 2005, pág. 344)

Retomando la crítica que realiza Nancy Fraser a Habermas en cuanto a que solo “idealice la esfera pública burguesa (Fraser, 1997, pág. 100), sino que deja de examinar otras esferas públicas no liberales, no burguesas, que compiten con ella (Fraser, 1997, pág. 103), la misma autora propone y cuestiona cuatro de los presupuestos centrales de la teoría de Habermas. El primero es lo que Fraser ha denominado libre acceso, paridad en la participación e igualdad social, mediante el cual, esboza en contra de Habermas que "la pretensión de plena accesibilidad afirmada por el público burgués no se concretó en realidad “(Fraser, 1997, pág. 108).

Para Fraser (1997 ) "los impedimentos informales a la paridad en la participación, que pueden subsistir incluso después de que todos hayan sido autorizados formal y legalmente a participar, nada lejos del panorama colombiano, que si bien la constitución trae consigo diferentes formas de participación ciudadana y que han sido reconocidas en materia jurisprudencial, la situación social y real del país en materia para este caso de las mujeres, frente a la inseguridad, las amenazas entre muchas otras investigaciones que sufren las voceras de dichas organizaciones, se hace o se torna en ocasiones que esas voces que puedan contar verdadera la realidad de dicho grupo y que sea tenido en cuenta por las autoridades administrativas de carácter departamental. Frente a la igualdad, diversidad y públicos múltiples contrario a la concepción Habermasiana que argumenta una esfera pública singular y de la cual Fraser ha de denominar contrario a ello "contra públicos subalternos para indicar que se trata de espacios discursivos paralelos donde los miembros de los grupos sociales subordinados inventan y hacen circular contra-discursos, lo que a su vez les permite formular interpretaciones opuestas de sus identidades, intereses y necesidades “ ( Pág. 115-116) es lo que hacen estas organizaciones con lo poco o mucho 
que se den a conocer, y a lo que Fraser denomina que han de contribuir a "extender el espacio discursivo..

En ese sentido, la paridad de la cual habla Fraser se logra mejor mediante una multiplicidad de públicos que a través de uno solo. Esto es cierto tanto para las sociedades estratificadas como para las sociedades igualitarias y multiculturales (de las cuales) también hace referencia en el primer caso defiende los contra-públicos subalternos formados en condiciones de dominio y subordinación. En el segundo defiende la posibilidad de combinar la igualdad social, la diversidad cultural y la democracia participativa.(Pág. 119)

Esferas públicas, preocupaciones comunes e intereses privados, Fraser (1997) sintetiza tal concepto y en contraposición a una concepción liberal individualista como un modelo republicano cívico que pone énfasis en una visión de la política como un conjunto de personas que razonan juntas para promover un bien común, que trasciende la mera suma de las preferencias individuales. La idea es que, a través de la deliberación, los miembros del publico pueden llegar a descubrir o crear este bien común" que si bien es objeto de observaciones y es un gran avance frente a la alternativa liberal individualista que propone Habermas frente a la sociedad liberal burguesa. (Habermas, 1998. Pág. 122- 124)

Igualmente si bien no se puede llegar a que todos concuerden, precisamente es a través de esa discusión que van a determinar lo que es común a ellos, no debe haber cómo lo denomina Fraser (1997) fronteras dadas a priori. Papel importantísimo de la sociedad y organizaciones de mujeres quienes conocen la realidad de tal evento y pueden deliberar y considerar los aspectos que requieran mayor estudio y protección por parte del estado, cuáles son sus necesidades y problemas inminentes dentro de ese conjunto, que no dan espera, que soluciones inmediatas pueden si bien no solucionar de raíz la situación de las mujeres en el Departamento del Meta frente a la protección de derechos, sin menguar por la protección de quienes lo sufren es decir de la población como tal. (Pág. 119-120-121) 
Finalmente y lo cual encaja perfectamente con las asociaciones o grupos que han de representar a las mujeres del Departamento del Meta es lo que denominó Fraser como públicos fuertes, públicos débiles: sobre la sociedad civil y el estado que critica a Habermas en tanto que este propugna por una separación radical entre sociedad civil y estado y a lo cual ella responde que no es necesario para que la esfera pública funcione bien. (Pág. 187)

En términos de Fraser esta opinión discursiva de tales organizaciones serviría de contrapeso al estado, frente a las posiciones y respecto a las funciones que ha de cumplir en pro del bienestar de las mujeres y sus requerimientos a través de la participación activa en la elaboración de las políticas públicas.

Aunado a lo anterior y según lo descrito, es preciso hacer mención a la teoría de Pierre Rosanvallon (2007) (La Contrademocracia) y Philip Pettit (1999) (La Democracia Disputatoria), como respuesta a la democracia meramente deliberativa, que permite materializar e ir más allá en términos de participación en tanto activa o negativa, como podemos proveernos de tales teorías, para tratar de responder y dar una alternativa real a los grupos sociales que intentan hacerse conocer y evidenciar la problemática latente frente a la ausencia y carencia total de políticas que identifiquen de manera particular las demandas de este grupo focal.

En un régimen democrático como Colombia en términos de Rosanvallon (2007. Pág. 284) se han de buscar formas de participación de los ciudadanos en las decisiones que les conciernen, como uno de los mayores rasgos de la evolución reciente de los regímenes democráticos; y para ello recurre al término de democracia participativa que mejor describe ese intento de esta sociedad por brindar esas garantías participativas a la sociedad, y en nuestro caso a los grupos que representan a la sociedad civil y que corresponde a una demanda social, la violación constante de los derechos humanos a las mujeres del Departamento del Meta. 
En términos de Rosanvallon (2007) pensaría que las ONG y organizaciones de carácter civil que pueden participar como representantes de las mujeres ha de funcionar como una forma de consolidar la democracia, en la medida en que están organizadas, realizan estudios y seguimientos previos a la situación, y que han de alertar a la opinión pública frente a determinada situación, pero con argumentos sólidos. El autor propone para ello el que " se desarrollen agencias ciudadanas de calificación para evaluar las acciones de ciertos organismos públicos. Se podría construir también observatorios ciudadanos para llamar la atención de la opinión pública sobre problemas emergentes o evoluciones preocupantes * (Pág. 291) indudablemente como el tema de la vulneración de derechos de manera reiterada al grupo poblacional de mujeres del Meta.

De lo que se trata en términos del autor es:

"hacer más visible la política debe consistir ante todo en el recordatorio permanente de la tarea que se trata de cumplir: constituir un pueblo inhallable en comunidad política viva. La simbolización es reflexión colectiva, relación con la decisión reafirmada de escribir una historia común; es el relato sensible y grave de los fracasos y las esperanzas que tejen esa empresa, es historia y memoria de la lucha de los hombres y las mujeres por tratar de instituir a pesar de todas las dificultades una sociedad de iguales“" (Pág. 299)

Ello es posible cuando existe una relación entre el estado y las demandas sociales que se materializan en la organización de grupos de la sociedad civil como las mujeres en busca o con la finalidad de incidir de manera activa en la elaboración de políticas que repercuten directamente e impactan en sus derechos.

Finalmente es la democracia Disputadora de Pettitte (1999) quien afirma que ". Las autoridades ejercerán un poder arbitrario, si las decisiones que toman pueden fundarse en sus intereses personales o banderizos, o en su interpretaciones personales o banderizas de las obligaciones que entraña ser legislador, administrador o juez“* (Pág. 240) y más aún las 
autoridades administrativas departamentales, si elaboran políticas públicas en las cuales el grupo destinatario de la misma no ha sido debidamente vinculado y participe de la elaboración, lo que puede conllevar a inconformismos de tipo social y más aún si dichos grupos no han sido tenidos en cuenta a la hora de tomar la decisión, bien indica el autor que las decisiones de carácter público no ha de ser impuesta arbitrariamente sino que "tiene que proceder de tal modo, que podamos identificarnos con ella y hacerla nuestra : que podamos ver en ella promovidos nuestros intereses y respetadas nuestras interpretaciones . (Pág. 241).

Cabe preguntarse desde esta perspectiva, si en la realidad las políticas públicas para las mujeres - si las hay- se identifican con la realidad y demandas sociales de las necesidades de la región en materia de protección de derechos a las mujeres, para darle a esta población una respuesta real, eficaz y efectiva.

Colombia es una democracia, y en estos términos será (más ) democrático en la medida en que el pueblo, individual y colectivamente, disfrute de la permanente posibilidad de disputar las decisiones del gobierno *, (Pettite. 1999. Pág. 242) como estas organizaciones sociales algunas organizadas como ONG han de disputar las decisiones que no se ajusten a sus realidades; sin embargo evitando que dichos colectivos no se conviertan en "victimas" en la medida en que sean en algunas ocasiones perseguidos precisamente por querer en términos de Pettit evidenciar sus deseos y creencias frente al gobierno. Deben constituirse mecanismos que permitan tal disputa de la mejor manera posible, pues finalmente el poder natural del estado, va estar siempre en condiciones superiores frente a este tipo de organizaciones, que no tienen el suficiente poder de contrarrestar tales decisiones.

Estos mecanismos a los que me refiero en materia de acceso a la Democracia Disputativa, han de llevarse a cabo en la medida en que se den las precondiciones de las que habla el 
autor para la existencia de tal disputabilidad democrática. De forma general son tres y las define de la siguiente manera:

* La primera es que la toma de decisiones se conduzca de modo tal, que haya una base potencial para la disputa. La segunda es que no haya sólo una base potencial para la disputa, sino que haya también un canal o una voz, por cuyo cauce pueda discurrir la disputa. Y la tercera es que, solo haya una base y un canal para la disputa, sino que exista además un foro adecuado en que hacer audible esa disputa: un foro en el que estimar la validez de las exigencias y determinar las respuestas adecuadas .. (Pettit. 1999. Pág. 242)

Pettit (1999) indica que tal base ha de constituirse en la medida en que las decisiones se tomen basadas en la negociación o en el debate, el cual ha de preferir el autor toda vez que tal disputa en forma de debate haciéndola atractiva el " que están abiertas a todos los que consigan argüir plausiblemente en contra de las decisiones públicas; no necesitan ustedes tener peso o poder particularmente grandes ,no al menos en principio para ser capaces de poner razonablemente en cuestión una decisión razonada “ (Pág. 245). Importante esto en la medida en que lo articulemos a nuestra realidad frente a las mujeres del Departamento del Meta, que como explica Pettit, la encajaría con la forma de disputa del debate toda vez que si bien no representan o no tienen algún poder grande frente a la sociedad o la capacidad de movilizar o cambiar realidades si con sus investigaciones y conocimiento de fondo puede carear al gobierno con argumentos con hechos más allá de la “norma ”, escrito o lo dicho .

\subsection{De la Participación en la constitución de 1991 - El caso práctico en el Departamento del Meta.}




\title{
1.3.1. Constitución Política de Colombia y su modelo de participación
}

La Constitución de 1991, trajo consigo una serie de principios, valores y principios que permean el nuevo sistema político de nuestro país y que fue necesario modificarlo a través del proceso Constituyente, el cuál determinó como una de sus principales características, la participación ciudadana:

\begin{abstract}
"para evitar la disolución (inevitable por el camino ensayado), de la sociedad civil y del Estado mismo. Por eso se establecieron nuevas bases de coexistencia, más a tono con el sino de la época: la solidaridad en lugar del egoísmo; el consenso en lugar de la imposición; la participación democrática en lugar del autoritarismo" (Quinche, 2012. pág. 12)
\end{abstract}

Cómo se observa, efectivamente la participación marca el punto de partida de la razón de ser de los ciudadanos dentro del estado y en ejercicio del poder político, en la medida en que permite la decisión activa de los mismos, no solo a través de la elección de sus representantes sino su inclusión en la toma de decisiones que los afecten de manera particulares y en comunidad. En ese sentido la Corte Constitucional (C-1017-2012) analiza que:

"La democracia participativa y pluralista otorga identidad al actual modelo constitucional. En contraposición con la Constitución de 1886, que basada en el concepto demoliberal clásico, circunscribía el ejercicio de la actividad política de los ciudadanos al sufragio universal y libre, la democracia constitucional contemporánea prevé un cambio cualitativo sobre este tópico, el cual (i) amplía las modalidades de participación democrática en instancias que van más allá que la elección representativa; y (ii) supera la concepción individualista, a través de la previsión de fórmulas que reconocen el pluralismo político, entendido como la necesidad de incorporar al debate democrático las diferentes tendencias ideológicas existentes en la 
sociedad, al igual que las distintas vertientes de identidad social y comunitaria, entre ellas las derivadas de perspectivas de género, minorías étnicas, juventudes, etc.”

En ese sentido y teniendo en cuenta lo analizado desde el documento, es claro cuando la corte constitucional es clara y en la misma línea del espíritu de nuestra constitución, es de gran importancia la percepción más allá de la simple participación que se agite con el sufragio, sino que la participaron cómo se analiza deba tener unos componentes cómo en el caso práctico motivo de investigación como lo es el enfoque diferencia desde la perspectiva de género y brindar las herramientas reales y efectivas para su correlación y participación con el estado en decisiones gubernamentales que las afecten e interesen.

Así, explica Quinche (2012) que la constitución de 1991 se ha concebido como un texto democrático que se ha caracterizado por:

" la división de poderes, las libertades públicas, la carta de derechos, los mecanismos de participación ciudadana, los mecanismos de defensa constitucional, las acciones constitucionales o los instrumentos de control de los distintos poderes, además de constituir una novedad en el sistema colombiano, pasan a ser los componentes democráticos centrales, de modo tal, que ni siquiera los poderes constituidos ( el Congreso de la República) pueden disponer libremente de ellos, en la medida en que no quedan sometidos a las emociones de las mayorías electorales, ni a los fundamentalismos deliciosos o de otra clase."

Estableció la carta política que la efectividad y eficacia de la participación radica y se materializa como lo explica Quinche (2012) “....En el establecimiento de los distintos instrumentos de control de poder, donde la Constitución de 1991 presenta su carácter democrático. Instrumentos como el control judicial de constitucionalidad, los mecanismos de participación y el grueso de las acciones constitucionales...” (Pág. 14) Por lo tanto la 
participación debe manifestarse y concretarse a través e instrumentos reales y accesibles a los grupos o poblaciones tradicionalmente discriminadas o históricamente relegadas de las acciones gubernamentales, lo que "implica la ampliación cuantitativa de oportunidades reales de participación ciudadana, así como su recomposición cualitativa en forma que, además del aspecto político electoral, su espectro se proyectó a los planos de lo individual, familiar, económico y social...” (Pág. 16)

Guzmán (2011) en su texto Democracia participativa en Colombia y en el mismo sentido, considera que:

“ La democracia participativa es el modelo democrático con el cual todos los ciudadanos intentan justificar su lugar en el sistema como sujetos políticos, eliminando de este modo la exclusión del ámbito político a las personas que no ostentan ninguna representación política.” (Pág. 32)

Entonces con esa finalidad propuesta en nuestro sistema político y específicamente en el texto fundante y carta de navegación, se determinó y caracterizó la participación como el elemento fundamental y transversal para el desarrollo de fines, los valores y principios constitucionales como el Preámbulo de la Constitución que determina que "determina las pautas interpretativas del texto constitucional" y la enmarca no solo como una finalidad, sino que caracteriza y encuentra la participación como Principio Constitucional, en el sentido de la democracia participativa o directa, así como la democracia representativa o indirecta; como un derecho fundamental del artículo 40, donde se establecen siete modalidades para participar en la conformación, el ejercicio y el control del poder político, como la enunciación y desarrollo de los mecanismos de participación democrática fijada en el artículo de 103 de la constitución y finalmente como un pluralista siendo "el rasgo de pluralismo más grande contenido en la Constitución, se relaciona con el tratamiento de las minorías históricamente discriminadas ....” (Quinche. 2012. Pág. 16) 
Ahora, desde el punto de vista constitucional son tres artículos constitucionales que materializan y establecen formalmente la participación ciudadana y su relación con el estado en la tomas de decisiones:

Artículo 3: La soberanía reside exclusivamente en el pueblo, del cual emana el poder público. El pueblo la ejerce en forma directa o por medio de sus representantes, en los términos que la Constitución establece. (Constitución Política de 1991)

En el primero de ellos y tal como lo explica la Corte Constitucional determina en ejercicio de la soberanía, tiene los mecanismos y medios que el mismo texto constitucional establece para su participación ciudadana, no solo para su correlación sino para la exigencia de derechos y garantías que le sean vulnerados o amenazadas, especialmente grupo o personas discriminadas.

Artículo 40 Todo ciudadano tiene derecho a participar en la conformación, ejercicio y control del poder político. Para hacer efectivo este derecho puede:

1. Elegir y ser elegido.

2. Tomar parte en elecciones, plebiscitos, referendos, consultas populares y otras formas de participación democrática.

3. Constituir partidos, movimientos y agrupaciones políticas sin limitación alguna; formar parte de ellos libremente y difundir sus ideas y programas.

4. Revocar el mandato de los elegidos en los casos y en la forma que establecen la Constitución y la ley.

5. Tener iniciativa en las corporaciones públicas.

6. Interponer acciones públicas en defensa de la Constitución y de la ley. 
7. Acceder al desempeño de funciones y cargos públicos, salvo los colombianos, por nacimiento o por adopción, que tengan doble nacionalidad. La ley reglamentará esta excepción y determinará los casos a los cuales ha de aplicarse.

Las autoridades garantizarán la adecuada y efectiva participación de la mujer en los niveles decisorios de la Administración Pública. (Constitución Política de 1991)

De todas las formas y maneras que se establecieron para la participación, ejercicio y control político, considera y permite la toma de decisiones a través de la participación en las elecciones que lleven a cabo con los mecanismos de participación, así como organizarse a través de movimientos o agrupaciones para la intervención en asuntos que les competan y que la misma ley no limite.

Ahora, estableció la propia constitución mecanismos claros y específicos que más tarde fueron desarrollados por la ley 134 de 1994, hasta el año 2015 que la Corte Constitucional analizó la constitucionalidad del proyecto de ley estatutaria que cambia algunas de las reglas y procedimientos para darle mayor fuerza, eficacia y efectividad a los mecanismos establecidos en el texto constitucional.

ARTICULO 103. Son mecanismos de participación del pueblo en ejercicio de su soberanía: el voto, el plebiscito, el referendo, la consulta popular, el cabildo abierto, la iniciativa legislativa y la revocatoria del mandato. La ley los reglamentará.

El Estado contribuirá a la organización, promoción y capacitación de las asociaciones profesionales, cívicas, sindicales, comunitarias, juveniles, benéficas o de utilidad común no gubernamentales, sin detrimento de su autonomía con el objeto de que constituyan mecanismos democráticos de representación en las diferentes instancias de participación, concertación, control y vigilancia de la gestión pública que se establezcan. (Constitución Política de 1991) 
En el mismo orden de ideas y teniendo en cuenta la situación de la participación de las mujeres en el Meta, es preciso que también las formas y herramientas de participación que nuestro sistema político y constitucional les brinde a los ciudadanos es la organización a partir de los movimientos sociales o grupos de la sociedad civil que buscan o persiguen fines comunes, por lo general para reivindicar garantías o derechos vulnerados o no reconocidos por las instancias gubernamentales e institucionales, así lo analiza Guzmán (2011):

"La democracia representativa, en especial los que dentro de ella defienden el pluralismo político como Dahl, Bobbio y Touraine, observan la conexión pueblo gobernantes con la intermediación de los movimientos sociales y los partidos políticos; alegóricamente, los ciudadanos individualizados en el sistema se agrupan en movimientos sociales que tienen como consignas luchas por el reconocimiento de diferentes derechos; son los encargados de presionar y redireccionar las directrices de los partidos políticos, los cuales constituyen, finalmente, el canal idóneo para ejecutar las agendas programáticas con el trabajo activo de sus líderes y representantes.” (Pág. 31-32)

Es decir, la participación no se agota en el ejercicio democrático de la elección como ya lo explico la corte y lo plasma la propia constitución, sino que a través de la organización de grupos y movimientos sociales y civiles, logran que sus representantes conduzcan sus agendas en torno y en pro del bienestar común de sus ciudadano, máxime cuando existen algunas poblaciones que tradicionalmente son excluidos y hay mayor vulneración y afectación de derechos.

Trae a colación y en ese sentido Guzmán, las experiencias de países desarrollados respecto a la importancia y la necesidad de los movimientos sociales en la democracia participativa y en el reconocimiento y protección de derechos y que el papel de Estado es directamente y en función del bienestar general de sus ciudadanos. Así explica que: 
"En los países desarrollados, el andamiaje anteriormente descrito al parecer funciona con algunas deficiencias, pero da resultado y los movimientos sociales son lo suficientemente fuertes para detener el ritmo de la ciudad, llamar la atención de los medios, agitar el ambiente de tranquilidad y hacerles entender a los gobernantes que el problema va en serio (ver, por ejemplo, el movimiento de los sin papeles en Francia, los indignados en varios países europeos, Anonymus, grupos ambientalistas y antiglobalización, entre otros). ” (Pág. 31-32)

Por lo anterior es fundamental que en Departamento del Meta brinde las herramientas necesarias para la participación real, activa y eficaz, en la medida en que no solo se materializan los postulados constitucionales, sino que logran el reconocimiento de las prerrogativas a las cuales tienen derecho y es la manera más práctica de comunicación entre el estado y sus asociados.

\subsubsection{Mecanismos de participación}

\subsubsection{Ley 134 de 1994}

Con la constituyente de 1991 entre muchas de sus características consagra en el ordenamiento el carácter democrático, pluralista y participativo con la finalidad de darle mayor participación y poder a los ciudadanos especialmente respecto a las decisiones que impliquen de manera positiva y negativa que pueda, para ello los preceptos constitucionales enunciados anteriormente fueron desarrollados mediante la Ley Estatutaria 134 de 1994 de los mecanismos de participación y que estableció en su exposición de motivos y teniendo en cuenta el proceso constituyente que le antecedía que:

La nueva Constitución diseñó una democracia diferente en la cual los colombianos tienen la posibilidad de ser los orientadores de su destino. El paso siguiente es construir las herramientas que hagan efectiva la participación ciudadana. El 
Presidente de la República ha resaltado en varias oportunidades la trascendencia del tema. Al Instalar las sesiones del Congreso señaló la participación como uno de los principios que deberán orientar la construcción del futuro. Dijo el Presidente: "Claro que la base de todo esto es la participación. La democracia se acomoda mejor a los espacios abiertos que a las prácticas excluyentes. Y es preferible reconocer que la repartición del ponqué, a la distribución de costos y beneficios no son asuntos técnicos sino decisiones que nos conciernen a todos. Y es por eso que la nueva Constitución prevé que la discusión del presupuesto y del plan sea liberal, trasparente y democrática. (Alcaldía de Bogotá, 1994)

Así mismo estableció con la finalidad de brindar herramientas jurídicas y la eficacia de los mismos:

Principios comunes aplicables a los distintos mecanismos de participación regulados por la ley estatutaria y reglas específicas para cada una de estas figuras. Los principios orientadores del proyecto están dirigidos a garantizar la participación efectiva, de la, ciudadanía en el proceso de toma de decisiones y a evitar que sean usados de manera abusiva e irresponsable. Las virtudes de la democracia participativa podrían desaparecer si en la regulación de la Iniciativa popular, de la consulta popular, del referendo, de la revocatoria del mandato, del plebiscito o del cabildo abierto no se hubiera tenido en cuenta la experiencia de otras legislaciones para determinar que controles son necesarios y cuáles características no son deseables. (Alcaldía de Bogotá)

Con el ánimo de vincular a todos los ciudadanos se establecieron diferentes mecanismos de participación de los ciudadanos en la toma de decisiones que les incumbe a todos y se fijaron reglas y principios jurídicos, con la intensión de vincularlos en los procesos que 
requieran de la participación ciudadana y su comunicación directa con el Estado y sus instituciones.

En su momento y en análisis de constitucionalidad del proyecto de ley estatutaria que analizó la corte constitucional en la Sentencia C-180 de 1994, respecto a la democracia participativa estableció que:

"El fortalecimiento y la profundización de la democracia participativa fue el designio inequívoco de la Asamblea Nacional Constituyente, luego traducido en las disposiciones de la Carta Política que ahora rige el destino de Colombia y de las que se infiere el mandato de afianzar y extender la democracia tanto en el escenario electoral como en los demás procesos públicos y sociales en los que se adopten decisiones y concentren poderes que interesen a la comunidad por la influencia que puedan tener en la vida social y personal.

La democratización del Estado y de la sociedad que prescribe la Constitución no es independiente de un progresivo y constante esfuerzo de construcción histórica que compromete a los colombianos - en mayor grado, desde luego, a las instituciones públicas y a los sujetos privados que detentan posiciones de poder social o político - y de cuyo resultado se derivará la mayor o menor legitimidad de las instituciones, no menos que la vigencia material de la Carta y la consecución y consolidación de la paz pública.

La concepción de participación democrática postula un vínculo estrecho entre los electores y los elegidos, que se traduce en la institucionalización del mandato imperativo, a consecuencia de lo cual se convierte en revocable. Además, incorpora mecanismos de participación como la consulta, el referendo, el plebiscito, la 
iniciativa ciudadana, etc., que hacen posible la intervención activa de los ciudadanos en la toma de decisiones."

Con lo cual pretendía establecer que no solo existe relación en la participación ciudadana con el proceso electoral de sus representantes, sino como las decisiones que se adopten desde el Estado debe y puede tener efectos y consecuencias en la vida de sus asociados y máxime cuando somos un estado pluralista y multiétnico que conlleva a que determinados grupo o poblaciones requieran para su protección derechos y prerrogativas que se ajusten a sus necesidades particulares.

Dichos mecanismo entonces y dada la finalidad que se trazó el legislativo en el momento de la elaboración de la Ley, quería dar herramientas para la participación activa, real y eficaz a los ciudadanos cuando sienta que sus representantes no cumplen los objetivos para los cuales fueron elegidos o cuando quieran decidir sobre temas que competen a la comunidad en general.

\subsubsection{Sentencia C-150 de 2015. Análisis de Constitucionalidad del proyecto de ley estatutaria de mecanismo de participación, Número 134 de 2011 CÁMARA (Acumulado 133 de 2011 CÁMARA) - 227 de 2012 SENADO "Por la cual se dictan disposiciones en materia de promoción y protección del derecho a la participación democrática”.}

El legislativo con el fin de fortalecer los mecanismo de participación desarrollados en el

Ley 134 de 1994, pretender dar mayores y mejores herramientas jurídicas y políticas que permitan la efectividad de la participación ciudadana desde la participación hasta el control de decisiones que afecten el bien común o particular de los ciudadanos y organizaciones civiles y sociales que representen interés particulares, para ello se propuso el siguiente objeto en el proyecto: 
Promover, proteger y garantizar modalidades del derecho de los ciudadanos a participar en las decisiones que los afectan y en la vida política, administrativa, económica, social y cultural y a controlar el poder político. Igualmente, desarrolla medidas para contribuir a la organización, promoción y capacitación de las organizaciones sociales con el objeto de que constituyan mecanismos democráticos de representación en las diferentes instancias de participación, concertación, control y vigilancia de la gestión pública. (Congreso Visible, 2015)

En el análisis de constitucionalidad del proyecto en mención, la Corte Constitucional analiza la democracia en el siguiente sentido:

La democracia en tanto eje axial del sistema jurídico colombiano así como los conceptos que usualmente se encuentran asociados a ella como "soberanía", "pueblo", "participación" y "representación" son empleados en la Constitución con varios propósitos, plenamente articulados con las implicaciones antes referidas. En efecto, tales categorías son incorporadas en la Carta Política para establecer la fundamentación del poder político ejercido por los diferentes órganos (la democracia como fuente de legitimidad), para reconocer y tutelar los derechos de participación de los individuos y la sociedad en la conformación y control del poder político e imponer deberes de respeto y protección al Estado y a los particulares (la democracia como fundamento de derechos y obligaciones) y para definir la forma en que tal poder opera democráticamente y los ámbitos en los que su aplicación puede exigirse (la democracia como expresión de reglas de funcionamiento y toma de decisiones).

Así como ciudadanos debemos respeto y tenemos deberes para con el funcionamiento del mismo, también la participación de los ciudadanos podemos intervenir e interactuar en la toma de decisiones que afecten nuestros intereses como individuos y como colectivo, por 
eso es necesario que la misma constitución nos brinde los momentos y herramientas para no solo controlar al estado en sus actuaciones sino para dialogar en las decisiones que vaya a tomar.

En ese sentido la Corte en sentencia C-150 de 2015 es clara en establecer el deber del Estado respecto a la participación ciudadana activa y eficaz como materialización de la democracia participativa, de la siguiente manera:

La Corte entiende que la participación como derecho de los ciudadanos y eje medular del ordenamiento constitucional vigente implica (i) el deber del Estado de abstenerse de adoptar medidas de cualquier tipo que impidan el libre ejercicio de la participación por parte de ciudadanos y organizaciones sociales, (ii) el deber de adoptar medidas de todo tipo que eviten que las autoridades públicas o los particulares interfieran o afecten el libre ejercicio de las facultades en cuyo ejercicio se manifiesta la participación y (iii) el deber de implementar medidas que procuren optimizar el desarrollo de las diversas formas de participación y que, al mismo tiempo, eviten retroceder injustificadamente en los niveles de protección alcanzados.

Y considera que para su materialización y efectividad respecto a los ciudadanos, el estado también tiene compromisos y por lo tanto tiene:

(i) El deber de abstenerse de estatizar la democracia y, en consecuencia, la obligación de proteger el pluralismo, (ii) Deber de promover formas de participación democrática que comprendan no solo la intervención de partidos o movimientos políticos sino también de organizaciones sociales de diferente naturaleza. (iii) Deber de promover estructuras democráticas en las diferentes formas de organización social. (iv) Prohibición, que vincula a todos los órganos públicos, funcionarios y particulares, de eliminar alguna de las dimensiones de la democracia. (v) Mandato de 
no sustituir a las autoridades estatales competentes en el desarrollo de actividades de control.

Dichos deberes endilgados al estado permiten garantizar a los ciudadanos el real ejercicio de participación y da la seguridad para constituirse en grupos o movimientos sociales que les permitan reclamar para sí, derechos, garantas y prerrogativas que les permitan ser activos dentro de la sociedad y controlar las actuaciones que puedan afectarlos negativamente. 


\section{CAPÍTULO 2 SOCIEDAD CIVIL Y MOVIMIENTOS SOCIALES}

\subsection{Generalidades de los Movimientos Sociales.}

La sociedad civil ha sido definida como la estructura básica sobre la cual reposan las instituciones cívicas y sociales. Estas instituciones son las que dan forma, organización y funcionamiento a los componentes esenciales para el desarrollo de dicha sociedad.

La sociedad civil es dinamizadora de la democracia, con ello buscando evitar los excesos del poder político actuando como veedores de procesos vitales para la consecución de los fines en una sociedad. Se instituye como función velar porque el contrato social que los une sea inviolable, y "amortigüe" los golpes políticos-económicos que puedan afectar dicho pacto. La virtud que hace que la sociedad sea un eje central, es la búsqueda de justicia y la solidaridad.

Michael Walzer, ha sostenido que la sociedad civil "hace referencia tanto al espacio cubierto por las asociaciones humanas no coercitivas como a la red de relaciones creadas para la defensa de la familia, la fe, los intereses y la ideología que cubren este espacio" (1998). Dentro de ella, entonces se pueden entender que coexisten todos los grupos sociales y asociaciones con el fin de participar activamente en la vida socio-política para la protección de intereses comunes e individuales. Se establece por tanto, que la democracia participativa es un requisito sine qua non para la transformación y la creación de una nueva sociedad, esto se articula a partir de la concepción de movimientos sociales bajo la concepción de la horizontalidad y el pluralismo.

En este sentido, se busca el pluralismo y destacar el papel del ciudadano por alcanzarlo. La 
sociedad civil requiere de "hombres y mujeres comprometidos y activos, en el ámbito de la nación, el Estado, la economía, y también las iglesias, vecindarios, familias y muchos otros escenarios." (Walzer, 1998, p 385).

Debido a ello, la sociedad civil se constituye como una fuente dinámica de ideas normativas, alianzas y apoyo. Para esto, John Keane estableció que era necesario encontrar un modelo democrático que postulara la integración del Estado y la sociedad para superar los problemas comunes que los aquejan (especialmente durante el siglo XX y en respuesta a los Estados totalitarios), siendo considerada dicha sociedad civil como "un agregado de instituciones, cuyos miembros participan en un conjunto de actividades no estatales - producción económica y cultural, vida doméstica y asociaciones de ayuda mutua-, y que preservan y transforman su identidad ejerciendo toda clase de presiones o controles sobre las instituciones del Estado." (1992).

De igual forma, doctrinalmente se considera que los movimientos sociales juegan un papel preponderante cuando a través de la participación ciudadana busca cambios de estructura y cambios de dinámicas estatales (bien sea desde el plano social, político o económico), "son capaces de cambiar instituciones, estructuras sociales e, incluso, las dinámicas de política económica que apuntalan la pobreza y el subdesarrollo.” (Williams, 2009, p.113).

Se analiza desde esta perspectiva que:

"La política de los movimientos sociales se forma a partir de la premisa de que el mundo es socialmente construido y que es tanto posible como necesario transformarlo para alcanzar la visión del movimiento de una sociedad justa y de las relaciones de poder dentro de ella. Las justificaciones para los aspectos que necesitan cambiar (agenda política) y por qué (análisis político), quienes los cambiaran (dirigentes, membrecía y representación) y como lo harán (acciones y estrategias) son 
las preguntas medulares de los movimientos sociales y los definen, además de diferenciarlos unos de otros. La existencia de los movimientos sociales y las visiones y acciones que presentan son inherentemente políticas en el sentido de que pretenden desafiar y transformar los sistemas de poder.” (Horn, 2013, p. 25).

Recordemos que históricamente los estudios sobre movimientos sociales se identifican en tres etapas: La primera, los movimientos obreros y su comportamiento colectivo desde la lucha de clases e ideologías políticas. Se consideran entonces como agentes de cambio social a partir de la teoría Marxista y Leninista. En ese entendido, la profesora Rosa Luxemburgo afirma que "en la historia de las sociedades basadas en el antagonismo de clase, el movimiento socialista es el primero que cuenta en todos sus estudios y en todo su camino con la organización y la acción directa y autónoma de masa." (1984).

La segunda etapa, llamada el "paradigma" de los nuevos movimientos sociales, se origina gracias a las revueltas de 1968 como consecuencia de la concepción de ideologías participativas, se considera que "la utilización creciente de formas no institucionales de participación política y la politización de temas tradicionalmente considerados como temas morales o económicos" (Garza, 2011, p. 113). Por este motivo, el profesor Claus Offe, clasifica las características principales de los paradigmas de la siguiente manera: 
CUNDRO 1

Caracteristicas principales de los paradigmas 5

\begin{tabular}{|c|c|c|}
\hline & Viejo paradigma & Nuevo paradigma \\
\hline Actores & $\begin{array}{l}\text { Grupos socieconómicos actuando } \\
\text { como grupos (en interés del grupo) } \\
\text { e involucrados en conflictos de } \\
\text { distribución. }\end{array}$ & $\begin{array}{l}\text { Grupos socieconómicos no } \\
\text { actuando como tales, sino en } \\
\text { nombre de colectividades } \\
\text { atribuidas. }\end{array}$ \\
\hline Consenidos & $\begin{array}{l}\text { Crecimiento econćmico y } \\
\text { distribución; seguridad militar } \\
\text { y social, control social. }\end{array}$ & $\begin{array}{l}\text { Mantenimiento de la paz, entorno } \\
\text { derechos humanos y formas no } \\
\text { alineadas trabajo. }\end{array}$ \\
\hline Valores. & $\begin{array}{l}\text { Libertad y seguridad en el consumo } \\
\text { privado y progreso material }\end{array}$ & $\begin{array}{l}\text { Autonomia personal e identidad, } \\
\text { oposición al control centralizado, } \\
\text { etcétera. }\end{array}$ \\
\hline $\begin{array}{l}\text { Modos de } \\
\text { actuar }\end{array}$ & $\begin{array}{l}\text { a) interno: organización formal, } \\
\text { asociaciones representativas } \\
\text { a gran escala. } \\
\text { b) externo: intermediación pluralista } \\
\text { o corporativista de intereses; } \\
\text { competencia entre partidos politicos, } \\
\text { reglas de la mayoria. }\end{array}$ & $\begin{array}{l}\text { a) interno: informalidad, } \\
\text { espontaneidad, } \\
\text { bajo grado de diferenciación } \\
\text { horizontal y vertical } \\
\text { b) externo: politica de protesta } \\
\text { besada en exigencias formuladas } \\
\text { en tórminos predominantemente } \\
\text { negatwos. }\end{array}$ \\
\hline
\end{tabular}

- Claus Offe, Partidos politicos y los nuevos movimientos sociales, Madird, Sistema. 1988, p. 182.

Gráfico1. Partidos políticos y los nuevos movimientos sociales.

(Offe, 1988)

Por tanto se analiza, que la nueva base social se sustenta no en la lucha de clases tradicional y el sector obrero, sino en una nueva "clase media" (estudiantes, amas de casa, desempleados, entre otros), que "conforman a los nuevos MS que generan nuevos valores y formas de organización y de acción" (Garza, 2011, p. 115). Por eso se habla de paradigmas pues gracias a superar "la concepción clásica" de años anteriores se deterioraron los enfoques tradicionales de los que derivaron finalmente los movimientos sociales.

La tercera etapa, se caracterizó por el acentuado auge en la década de 1980 marcada por el fenómeno de globalización e institucionalización de los movimientos. Esta última etapa especialmente significativa en cuanto a la constitución teórica de los movimientos sociales; respecto a ello el profesor Melucci afirma que "la institucionalización parcial de los movimientos sería, en síntesis, la característica dominante de estas nuevas formas de acción colectiva." (Garza, 2011, p. 114). 
Lo anterior es conocido con el nombre de nuevos movimientos sociales a partir de la cual se organiza una estructura dimensional que tiene en cuenta : "la base social, demandas, formas de acción y valores, ofrecen un buen punto de partida para estudiar a los MS. Al contrastarlas con información empírica pueden resultar útiles aunque a veces rompa con las constantes tradicionales." (Garza, 2011, p. 116).

En los nuevos movimientos sociales podemos identificar a grupos pacifistas, ecologistas, ONGs, movimientos feministas, entre otros grupos. Todos estos movimientos son considerados como la trascendencia de estructuras clásicas a partir de la inclusión, el pluralismo y las reivindicaciones socioeconómicas. Los nuevos movimientos sociales, "tienen la capacidad inventiva para poner en funcionamiento formas de protesta poco institucionalizadas (ocupaciones locales, huelgas de hambre) al añadirles con frecuencia una dimensión lúdica y una anticipación sobre las expectativas de los medios de comunicación masivos, enfatizan la autonomía y la resistencia al control social" (Mancero, 2010, p. 174).

Es por lo anterior, que se considera que los movimientos sociales deben surgir a partir de la cohesión de intereses comunes, lazos de solidaridad, acción colectiva y redes de comunicación, esto por supuesto, debe estar encaminado al logro de un fin común, que en este caso sería la visibilización y la influencia como movimientos en el planteamiento de políticas sectoriales de acuerdo a las necesidades sociales de un determinado momento. Es por ello que Charles Tilly, establece que "(...) este proceso ocurre a través de las redes sociales y políticas en que convergen individuos en torno a fines comunes; a través de las oportunidades políticas que les dan acceso a canales de expresión de acción colectiva; y a través de la construcción de nuevos significados a partir de los cuales emergen nuevos actores colectivos." (1998).

Lo anterior inicia a través de formas de acción colectiva, pues estas "surgen en respuesta a situaciones de desigualdad, opresión y/o demandas sociales, políticas, económicas o culturales 
insatisfechas. Están conformados por 'una base organizada que comparte una agenda política de cambio y la lleva adelante a través de la acción colectiva.” (Horn, 2013, p. 1)

Deben entonces, estos agentes sociales buscar un justo equilibrio entre el Estado y la sociedad, y establecer unos fines que definirán la vida en común. Es a partir de la prosecución de estos principios y ciertos objetivos sociales donde aparecen los movimientos, para la construcción de una sociedad democrática en todas sus dimensiones y que con su actuar puedan tener incidencia en la política pública. Por ello se afirma, que es preciso destacar que "la perspectiva de los movimientos sociales nos traslada al escenario de la definición de la realidad, a la esfera de la (re) producción de sentidos y a la pluralidad como marco analítico de lo posible." (Santamarina, 2008, p. 118).

Los movimientos sociales (como asociaciones voluntarias) son grupos que pertenecen y son fundamento de la sociedad civil que se compone "con estructuras y asociaciones voluntarias, no estatales ni económicas, que arraigan las estructuras comunicativas de la opinión públicas en el mundo de la vida, tales como la familia, movimientos sociales o asociaciones cívicas, que expresan opiniones e intereses a través del espacio de una esfera pública autónoma”. (Cortina, 1998, p. 8). Surgen como una categoría de los actores sociales, con el fin de lograr una transformación en el estado democrático y conseguir la dispersión de poder encaminado a conseguir inclusión en el marco de creación de políticas sociales.

\subsection{Movimientos Sociales desde la perspectiva de mujeres.}

Salvador Martí, ha definido que un movimiento social "es un agente de influencia y persuasión que desafía las interpretaciones dominantes sobre diversos aspectos de la realidad, incidiendo así en todos los ámbitos de la política." (Martí, 2004, p.79). Como sujetos colectivos, buscan modos de organización alternativos de lucha para cambiar la estructura social, "algunos movimientos sociales clásicos son el movimiento feminista, el movimiento 
obrero, el movimiento por los derechos civiles de la población de color, entre otros (Mora, 2014, p. 5).

A partir de allí se analiza, que las luchas comunes por temas vitales buscan instituciones participativas, descentralización, toma de decisiones inclusivas y justicia social, que pueden formar el núcleo de un nuevo tipo de poder y es el poder las personas como autores del contrato social que en principio mencionamos.

De acuerdo a François Houtart podemos tomar dos ejemplos claves que podrían ejemplificar el alcance de los movimientos en América Latina, "las organizaciones de pueblos indígenas han adquirido una importancia grande también en los últimos años. La resistencia contra el $\mathrm{ALCA}^{1}$ es uno de los grandes éxitos que han conseguido juntos muchos movimientos sociales, tanto obreros como campesinos e indígenas; en Europa, el nacimiento de nuevos movimientos: sindicatos, ecológicos, sobre las finanzas internacionales (ATTAC ${ }^{2}$ )”. (2005)

Aunque los movimientos sociales se han presentado a lo largo de la historia, es imposible unificar un solo criterio respecto de su eficacia de acuerdo a los cambios conseguidos. Sin embargo, la doctrina al respecto, ha señalado que los cambios pueden verse reflejados en los siguientes ámbitos:

“- El simbólico: con cambios en los sistemas de valores, opiniones, actitudes y conductas sociales e individuales; y la formación de nuevas ideas colectivas; - El interactivo, con la capacidad de hacer emerger nuevos actores políticos o de generar cambios en la estructura de representación política y en los sistemas de alianzas;

- El institucional, con la habilitación de nuevos procedimientos administrativos y la creación de nuevos espacios y mecanismos estables de negociación con autoridades;

\footnotetext{
1 Área de Libre Comercio de las Américas.

${ }^{2}$ Movimiento Francés de Acción cívica.
} 
$\mathrm{y}$

- El sustantivo, empujando el cambio de ciertas políticas gubernamentales en marcha; obteniendo derechos individuales, civiles y sociales: y, en definitiva, creando nuevas oportunidades para la movilización.” (Martí, 2004, p. 2)

En el contexto de los últimos años se han presentado, nuevas olas de movimientos a lo largo del mundo. No obstante, haciendo énfasis nuevamente en América Latina podemos decir que el auge de los movimientos sociales de presentó en los inicios de la década de los noventa con la ola neoliberal que se expandió por el mundo. En ésta época, el impacto se evidenció en "las profundas y regresivas consecuencias en términos sociales y democráticos que la aplicación de estas políticas supuso (de las cuales la pauperización de masas es una de sus expresiones más trágicas) fueron el resultado de las agudas transformaciones estructurales” (Boron, et al, 2006, p. 228).

En esta misma línea de pensamiento, se ha establecido el tema de género y los derechos de las mujeres son relevantes al momento de hablar de inclusión total en el concepto de acción colectiva y pluralismo (ejes centrales de los movimientos sociales) para dar una aproximación global o unificada.

De este modo lo establece el informe elaborado por Bridge ${ }^{3}$ :

"A fin de ser exitosa, cualquier acción o intervención en torno a los derechos, la democracia y la igualdad debe incluir y valorar la igualdad de género como parte de su análisis y metodología para el cambio. Sin esto, es poco probable que las intervenciones tengan éxito en sus objetivos de contribuir a la igualdad para todas las personas y a una transformación social más holística y completa. Integrar perspectivas de género no se trata solo de 'incluir' a mujeres o 'pensar' en hombres y minorías de género, sino más bien de considerar lo que una política de género

\footnotetext{
${ }^{3}$ Agencia especializada para el desarrollo de género del Reino Unido.
} 
proporciona en cuanto a maneras alternativas de ser, ver y hacer que por sí mismas sirvan para transformar las relaciones de poder patriarcales." (Horn, 2013, p. 2)

Desde la perspectiva de género también podemos señalar, cuatro momentos históricos a partir de movimientos sociales que han creado espacios propios para hacer llegar las demandas de derechos de las mujeres a la esfera pública y de igual forma para ejercer influencia en la creación de políticas públicas en el tema.

Frente a ésto, debemos resaltar lo siguiente: El primero de ellos, es el trabajo igual- salario igual, defendido por movimientos como la Unión Gremial Femenina en Argentina (que apoyaba toda huelga y solicitada reglamentación del trabajo de mujeres y niños), movimiento de la mujer en la industria textil en Colombia y en Uruguay la Resistencia de lavanderas.

El segundo desarrollo, se ubica desde el derecho al voto: el sufragismo como expresión del movimiento de la mujer desde la década de los veinte hasta los cincuenta, con Serafina Dávalos en Uruguay, la función conciliadora de la mujer en la sociedad en Chile desarrollado por organizaciones masivas de mujeres como la FECHIF, la liga feminista para el sufragio en Costa Rica en 1949, entre varios acontecimientos. El tercer punto se ubica, desde la mujer considerada como parte plena de la sociedad, a partir de Eva Perón con el partido Peronista femenino, la consolidación de derechos y "agentes del nuevo desarrollo social" (Luna, 2006, p. 657) con el Frente único Pro - Derechos de la mujer en México y la Federación de mujeres Cubanas en busca la igualdad y la mejora de la situación de las mujeres en 1960.

El último punto, fue el reconocimiento de la madre como papel fundamental en la sociedad: los clubes de madres en Sao Paulo, el club de madres del Barrio Cruz de Mayo en San Martín de Porres, todos con el fin del respecto por su rol en la sociedad como creadoras de vida y de alimentos para la sociedad. 
De igual forma, en América Latina se ha considerado al feminismo como movimiento social (constituyendo los elementos primordiales como la solidaridad y reclamar cambios sociales, relaciones sociales mediante ruptura de los límites del sistema normativo tradicional y capacidad de producción de nuevas normas y legitimación de la sociedad) y crítico que ha trascendido como actor social, surgiendo con ello la Conferencia Mundial sobre la mujer celebrada en México en 1975. Las conferencias regionales se destacan por incorporar a las mujeres en los diversos ámbitos político, social y económico), acceso igualitario, educación, salud, mercado laboral, estrategias de paz, discriminación salarial, derechos reproductivos, entre otros aspectos relevantes que constituyen un ámbito esencial para el desarrollo de la mujer como agente social.

Como influencia internacional el tema de movimientos sociales y la inclusión de derechos civiles y políticos de la mujer, se enmarcó en las conferencias internacionales de organismos interamericanos. En la conferencia interamericana en Chile en 1923 se avanzó por adoptar una legislación acorde al contexto y que se comprometiera a eliminar la desigualdad que afectaba a las mujeres; en la conferencia interamericana en Cuba en 1928 " una comisión del partido nacional de feministas de Cuba, sustentó ante los delegados, que el estudio de los derechos políticos de la mujer debía integrarse al programa de la conferencia." (El tiempo, 1928, p. 17). Gracias a ello, fue aprobado el Comité Interamericano de mujeres (CIM). "El debate de organismos internacionales contribuyó a la adopción de medidas para mejorar las condiciones de la mujer trabajadora y legitimar las demandas que fueron incoándose por la igualdad social" (Villarreal, 1994, p. 70).

En el plano nacional, surge en Colombia a partir de la década de 1970 el movimiento social de mujeres que se perfila como un actor colectivo plural que abarca pensamientos, posiciones, etnias, clases, entre otros. Como movimiento social nacido en esta época debemos nombrar a las trabajadoras bananeras y el movimiento sindical de mujeres, la cuales participaron en búsqueda de alianzas para mejorar y posicionar sus derechos e intereses de género, “(...) el 
movimiento social de mujeres giró en torno a temáticas de identidad, empoderamiento, violencia que afecta a las mujeres.” (Tribunal Nacional de Mujeres, 2005, p.163)

De igual forma, surgieron movimientos como la Organización popular de mujeres (ej: la Asociación de Madres Comunitarias por una Colombia Mejor) con iniciativas en sectores populares y proyectos locales de participación; las organizaciones sindicales apoyadas por la comisión femenina de la $\mathrm{CUT}^{4}$ en su lucha contra la discriminación de la mujer y el reconocimiento a la importancia que tiene la mujer en cuanto a participación en la actividad sindical; las organizaciones campesinas y con el Ministerio de Agricultura en 1984 se impulsa la organización femenina, como parte de la política agraria para la mujer campesina.

Se crea de igual forma, la Asociación Nacional de Mujeres Campesinas e Indígenas de Colombia (ANMUCIC) "inserta en la política agraria, con el objeto de fortalecer la participación de la mujer rural, mejorar su calidad de vida y lograr que los programas de desarrollo lleguen a ella.” (Páez, et al, 1989, p. 9). La asociación ha logrado llegar a instancias de toma de decisiones en materia de política agraria, dotación de tierra y adjudicación a las mujeres; en la Asamblea Nacional Constituyente participó una lista de mujeres como movimiento feminista con el fin de hacer parte activa del proceso político del país y por último se dio la creación de la Red Nacional de Mujeres en 1991 como propuesta de inclusión social, diversidad, enfoque de género y derechos.

El movimiento feminista en América Latina, ha obtenido logros significativos en favor de la igualdad y la equidad de las sociedades:

“- en la esfera política, colocó el tema de las cuotas y la representación política paritaria, con todas sus implicancias para la democracia y la ciudadanía;

\footnotetext{
${ }^{4}$ Central unitaria de Trabajadores de Colombia.
} 
- en la esfera económica, logró que la cuestión del trabajo doméstico no remunerado formara parte del diseño de las políticas públicas en algunos países;

- en el ámbito de los derechos, derribó la frontera público/privada, poniendo fin a la impunidad en torno a la violencia contra la mujer;

- en el ámbito de las políticas públicas, otorgó legitimidad y estatuto jurídico a las políticas transversales.” (Virreira, 2009, p.94)

Así mismo, como antecedente histórico se encuentra que durante el siglo XIX y XX, se intentó obtener el acceso formal al espacio político a la ciudadanía por parte de las mujeres, por eso se habla de que el auge principal de presentó durante los años 60 y 70 pues en estos años se marcó la pauta para que las mujeres formaran parte de la esfera pública y consiguieran mejorar su calidad de vida en temas como el acceso a la educación y el trabajo asalariado y justo, "durante los años 60 y 70, centró su atención en el hecho que, en la época de la igualdad formal, ser ciudadana seguía sin ser equivalente a ser ciudadano, ya que no daba acceso a los ámbitos de poder en igualdad de condiciones; y se orientó a desvelar y denunciar el carácter sexuado de la vida cotidiana." (Alfama, 2009, p. 2)

En lo concerniente a la perspectiva concreta se identifica que "en el contexto de los derechos de las mujeres y la justicia de género, los movimientos de mujeres han sido pioneros en cuanto a impulsar agendas progresistas y desafiar las normas sociales y culturales con prejuicios de género tanto a nivel popular como en las leyes, las políticas y las practicas institucionales, teniendo a su haber grandes logros en lo concerniente a establecer la igualdad formal y transformar el pensamiento y la practica social en el último medio siglo." (Horn, 2013, p. 11).

Esto demuestra que los movimientos sociales siguen siendo una fuente amplia de cambios significativos en busca de eliminar la desigualdad y las restricciones frente a ciertos temas 
desarrollados dentro de la sociedad, no obstante, se debe hacer énfasis en que no corresponde solo como logro esencial la eliminación de estos factores excluyentes, sino por el contrario se tiene como fin la propuesta de ciertos modelos, la injerencia en la toma de decisiones trascendentales, la participación en la elaboración de políticas estatales y la estructuración de nuevas concepciones sociales, económicas y políticas.

\subsection{Impacto de los Movimientos Sociales de las mujeres en la Elaboración de Políticas Públicas.}

La presencia de las mujeres en los movimientos sociales ha establecido a través de la historia estructuras conectivas de movilización cuya dinámica ha generado movimientos feministas, redes sociales y dinámicas movilizadoras, "la presencia de las mujeres en los movimientos sociales parece, en términos generales, escasa y marginal excepto en las reivindicaciones explícitamente feministas. Aunque hemos visto que para participar tienen que vencer más obstáculos que los hombres, el problema, a nuestro entender, no es la baja presencia de las mujeres en los movimientos sociales, sino que la forma como estamos definiendo en qué consiste participar en movimientos sociales suele invisibilizar los aportes de las mujeres." (Alfama, 2009, p. 12).

En este aspecto, se puede determinar que existe una punto de equilibrio de los movimientos sociales con la movilización de género, "una mirada más atenta revela rápidamente que, por lo menos en este caso, las mujeres son mayoría, con un papel muy activo y fundamental; lo que realmente es escaso es solo su presencia en los espacios visibles y formalizados de la movilización. Las diferencias y desigualdades de género, pues, a la vez que dibujan unos determinados límites y obstáculos (para el reconocimiento y el acceso a los espacios de poder internos), también pueden facilitar la acción política.” (Alfama, 2009, p. 12).

Ahora bien, en un ámbito legal podemos hacer énfasis en instrumentos internacionales que han 
institucionalizado o agrupado la búsqueda de mecanismos para poder obtener desde los movimientos sociales una protección adecuada a la mujer en su desarrollo dentro de la sociedad.

Frente a las organizaciones internacionales podemos resaltar la labor de ONU mujeres, quien ejecuta programas de atención de género a través de grupos de la sociedad civil en diferentes países resaltando la labor comunitaria en diferentes naciones, participación en la vida política, planificación local, entre otros logros respecto a la perspectiva de género.

Así mismo, en el marco internacional se han evidenciado avances con la ayuda de estos movimientos colectivos para la defensa de los derechos de la mujer, esto se puede ver reflejado en la construcción de instrumentos internacionales para la protección y la garantía de los derechos de la mujer, como lo son : la Convención para la Eliminación de todas las Formas de Discriminación contra la Mujer (CEDAW), la Declaración y Plataforma para la Acción de Beijing, el Convenio 183 de la OIT $^{5}$ y la Convención de Belém Do Pará.

En la misma medida, se han creado distintas organizaciones con el fin de mejorar y promocionar el desarrollo del enfoque de género en el mundo. Entre ellos tenemos, el Instituto Internacional de Investigaciones y Capacitación para la Promoción de la Mujer (INSTRAW), el Fondo de Desarrollo de las Naciones Unidas para la Mujer (UNIFEM), la UNICEF ${ }^{6}$ mujer con el trabajo de vigilar por la protección de la Convención sobre la eliminación de todas las formas de discriminación contra la mujer ${ }^{7}$, y la $\mathrm{OEA}^{8}$ con la Comisión interamericana de mujeres con el fin de proteger los derechos humanos de las mujeres. Todas estas organizaciones trabajan de la mano con grupos focales y movimientos sociales nacionales,

\footnotetext{
${ }^{5}$ Organización Internacional del Trabajo.

${ }^{6}$ United Nations Children's Fund.

${ }^{7}$ UN. The United Nations Committee on the Elimination of Discrimination against Women (CEDAW), 1982.

${ }^{8}$ Organización de Estados Americanos.
} 
para dar desde la perspectiva de género un cumplimiento a los derechos consagrados en el ordenamiento jurídico nacional e internacional.

Haciendo alusión al contexto histórico en nuestro país, desde 1920 se afirma, que el progreso de los derechos de la mujer a través de movimientos sociales, tiene como antecedente en la crítica por la desigualdad de la mujer, especialmente en lo que se relaciona a la educación, "el mejoramiento de la situación educativa de la mujer, constituyó pues, un reclamo que desde las primeras décadas de siglo hicieron las mujeres y los sectores más democráticos de la sociedad, también fue la condición que le permitió a las mujeres vincularse al espacio público de una manera transformadora.” (Villarreal, 1994, p. 67). Lo anterior se logró a través de espacios intelectuales, de periodismo, medios de comunicación y centros de estudio.

La participación en espacios públicos se dio de igual manera, a principios de siglo, a través de espacios cívicos y actividades de solidaridad social, "las actividades caritativas y/o de acción social, tuvieron un papel ideológico de velar por cuestionamientos que se hacían en términos de desigualdad social y subordinación de la mujer.” (Villarreal, 1994, p. 71).

Así mismo, aparecen expresiones de las mujeres en otros ámbitos, como la participación colectiva del movimiento de las bananeras, huelga femenina de fabricato (alza de salarios, rechazo a acoso sexual, entre otros), presencia femenina en el partido socialista, asociaciones sindicales (Maria Cano una de las mujeres representativas en este aspecto), la Alianza femenina de Medellín, la Unión de mujeres demócratas y patronato de obreras de Medellín. Estas siendo solo algunas de las representaciones de los espacios que se abrieron las mujeres para hacer parte de la organización social del país y así mismo cuestionarla para reivindicar sus derechos.

En el entorno colombiano, en el tema de género para el año 2013, se estima que aproximadamente las mujeres constituyen el 52\% de la población total del país y representan 
el 54\% de la población pobre. ${ }^{9}$ Estas cifras demuestran que la población femenina ha sido tradicionalmente excluida y discriminada, los índices de violencia de género no son favorables a la situación de la mujer pues se cree que las cifras sobrepasan el $52 \%{ }^{10}$; por ello desde un análisis de los derechos humanos de las mujeres en Colombia vemos que se puede entrelazar directamente este tema con la lucha de los movimientos sociales de las mujeres y del feminismo.

Es por esto, que desde el Tribunal Nacional de Derechos sociales, económicos y culturales para la mujer creado en Colombia, se afirma que "el debate por el reconocimiento, la ampliación y protección de los derechos humanos de las mujeres se ha dado principalmente en el espacio público, en el cual las ciudadanas y los ciudadanos deliberan sobre sus problemas comunes; es el lugar para la producción y circulación de discursos, es un espacio para las relaciones discursivas, un foro para debatir y deliberar". Por eso es importante que desde la esfera pública se cuente con la capacidad de participación e inclusión, situación que sucede a través de los movimientos sociales mencionados en principio.

Lo anterior es el motivo por el cual la profesora Nancy Fraser, considera que existen amplias concepciones de injusticia, situación que es directamente aplicable a la situación de exclusión actualmente con respecto al enfoque de género, para que las sociedades puedan superar dichas exclusiones debemos tener en cuenta dos aspectos desde la esfera pública, la primera, la injusticia económica y la segunda injusticia cultural.

Afirma Fraser, que las dos se entrecruzan pues en la práctica "se fuerzan mutuamente de manera dialéctica, resultando a menudo en un círculo vicioso de subordinación cultural y económica" (1996). Por ello la solución para la injusticia debe ser "algún tipo de

\footnotetext{
${ }^{9}$ Departamento Nacional de Planeación, Bogotá, 2002.

${ }^{10}$ Instituto Nacional de Medicina Legal y Ciencias Forense. Bogotá. 2012.
} 
reestructuración político-social, redistribución del ingreso, reorganización de la división social y sexual del trabajo y transformación de otras estructuras económicas básicas” (1996).

Ahora bien, haciendo referencia nuevamente al desarrollo doctrinal del término sociedad civil, Norberto Bobbio ha descrito a ésta, como el lugar en donde surgen y se desarrollan los conflictos económicos, sociales, ideológicos entre otros, razón por la cual las instituciones estatales tienen "la misión de resolver mediándolos, previniéndolos o reprimiéndolos" (1985). Debido a ello, las personas inmersas en el conflicto particular, conforman grupos $\mathrm{u}$ organizaciones mediante las cuales se van a ver reflejados sus intereses y para poder exigir una actuar institucional, estos grupos o movimientos entonces surgen (de acuerdo con Bobbio) en contrapuesta al Estado.

Los sujetos identificables a partir del desarrollo de esta noción, son las organizaciones, movimientos de defensa de derechos y liberación de la mujer, grupos de interés, asociaciones con fines sociales o políticos, entre otros, que finalmente van a legitimar el actuar de la sociedad civil a través de dichas exigencias.

Lo expuesto anteriormente, tiene directamente incidencia en la aplicación eficaz de la democracia. Recordemos que la sociedad civil destaca el papel fundamental que juega el ciudadano dentro de un sistema como el mencionado, especialmente si está enfocado a resaltar que existen otros "centros de poder además del Estado" (Bobbio, 1984, p. 34). Allí, es cuando se hace alusión al sentido pluralista que debe conllevar la democracia y la verdadera participación de la sociedad como legitimador de la estructura, (es por esto que se habla en términos de democracia representativa y democracia directa) especialmente relacionándolo con la distribución de poder y la democratización de la sociedad civil.

En términos generales, según Amenta y Caren existen cuatro argumentos principales del impacto de los movimientos sociales en los Estados: “a) la movilización o la acción colectiva 
en sí misma tiende a ser efectiva; b) una vez emprendida la movilización, ciertas estrategias o formas de organización son más efectivas que otras; c) las oportunidades o contextos políticos favorables son benéficos para la movilización contenciosa y, d) la acción colectiva está políticamente mediada, en otros términos, las combinaciones específicas de formas de movilización, acción y condiciones políticas determinan las consecuencias de los movimientos." (Amenta \& Caren, 2004, p. 461).

Es por ello que se considera que "los movimientos gradualmente se incorporan en las estructuras y procedimientos existentes, aún sin transformar las reglas básicas del juego. Este camino guía a la institucionalización, pero también simplemente a la integración de las demandas de los movimientos en las agendas y políticas públicas." (Giugni, 1998, p. 371).

De igual forma, dentro del contexto de la sociedad civil tenemos que hacer mención a lo que tiene que ver con opinión pública, pues es a través de este sistema que se va establecer un canal de transmisión entre la sociedad civil y el Estado, es a partir de ese diálogo, que se vivifican los consensos y se materializan los derechos.

Es por ello, que no se debe trabajar al Estado- Institución como una esfera aislada de la sociedad, sino como un sistema que se encuentra al interior de dicho Estado pues de allí van a surgir la relación individuo- Estado, tal como se establece precisamente en la teoría de Bobbio "Sin opinión pública, lo que más concretamente significa sin canales de transmisión de la opinión pública, que se vuelve pública precisamente porque es transmitida al público, la esfera de la sociedad civil está destinada a perder su función y finalmente a desaparecer."(Giugni, 1998, p. 372)

En este sentido, (el de la opinión pública) Habermas habla de la resonancia y la visibilización de los problemas de la sociedad, que acarreará que la discusión respecto de un tema en específico se lleve a cabo en las demás esferas y adquiera relevancia. Sin embargo, dicha 
relevancia se conseguirá a través de las asociaciones, organizaciones y movimientos que mencionamos en principio, por ello, "quienes recogen la resonancia que las constelaciones de problemas de la sociedad encuentran en ámbitos de la vida privada, la condensan y elevándole, por así decir, el volumen o voz, la transmiten al espacio de la opinión pública-política.” (1998)

En el marco de la participación y la inclusión de actores en el desarrollo de temas trascendentales que hemos mencionado, se puede traer a colación la ejecución y preparación en el tema de políticas estatales encaminadas a solventar la problematización vigente en la sociedad. En este contexto se resalta entonces la efectiva implementación de las directrices desarrolladas dentro del Estado democrático para tratar de solidificar el sistema, en esta medida se busca que las políticas públicas, sean cabalmente diseñados de manera que integre a todos los sectores (esferas sociales en caso concreto), y no sea netamente la diferenciación de posiciones e intereses públicos o privados. Por esto, es necesario que "el proceso de implementación de una política requiera desarrollar una estructura organizativa, con roles bien definidos, un claro plan de acción que comporte también un permanente monitoreo y evaluación de los resultados conseguidos." (Alberti \& Villena, 2014, p.32).

Es en esta medida, es indispensable la total coherencia entre la comunicación por parte de la sociedad civil y las estructuras organizacionales, pues se debe crear una verdadera interacción (sea a través de la opinión pública antes mencionada u otros medios) que asegure la cooperación necesaria para lograr los objetivos, especialmente encaminados al beneficio común.

Es a partir de ello, que "naturaleza e implementación de políticas públicas en general -y en modo particular aquellas dirigidas a reducir los niveles de pobreza, desigualdad y exclusión social- se basa en una hipótesis general: el prevaleciente modo de hacer política y el carácter 
del Estado afectan directamente la eficacia, autonomía, coherencia, y continuidad de las políticas públicas." (Alberti \& Villena, 2014, p. 33).

Es precisamente desde el análisis anterior, que se resalta la importancia y la influencia en la creación de políticas públicas, pues los movimientos sociales están correlacionados primordialmente con la participación ciudadana directa e indirecta, bajo el entendido que en una sociedad democrática es necesaria "una mirada desde todas las formas de participación sociopolítica, o bien, la intervención de las personas en la gestión pública cuando emprenden acciones para influir en la toma de decisiones dentro de las instituciones del Estado" (Pendhs, 2001, p. 343). 


\section{CAPÍTULO 3 \\ POLÍTICA PÚBLICA}

\subsection{Generalidades de la política pública.}

Desde la perspectiva de Pierre Müller, se establece el concepto de política pública como "la ciencia del Estado en acción" (2002, Pág. 130), analizando que es de origen anglosajón y proviene de diversas áreas del saberes, para analizar si la política pública genera para la realidad social una cuestión nueva.

Para autores como Yves Mény y Jean Claude Thoening se definió como el "Programa de acción gubernamental en un sector de la sociedad o un espacio geográfico" (Ibídem, Pág. 48) Termina siendo el objeto de esta la gestión de una relación global-sectorial (RGS). Lo propio de una sociedad sectorial es manejar de manera permanente una infinidad de desfases y desajustes entre los sectores cuyos modelos de reproducción chocan entre sí constantemente.

El concepto de política pública se ha observado desde diversas perspectivas, pero para la aplicación en Colombia se ha tratado de dar una propuesta de definición que se adapte a nuestras necesidades: "proceso integrador de decisiones, acciones, inacciones, acuerdos e instrumentos, adelantado por autoridades públicas con la participación eventual de los particulares, y encaminado a solucionar o prevenir una situación definida como problemática. La política pública hace parte de un ambiente determinado del cual se nutre y al cual pretende modificar o mantener.” (Velásquez, 2009 Pág. 149 a 187) 
En esta se aplica los conceptos del inglés de "policy" y "politics", siendo el primero un referente de intervención en situaciones desde el gobierno, en la segundo se debe entender el arte y ciencia de gobernar. La influencia del concepto del género ha afectado los procesos de inclusión y la aplicación de los enfoques desde una forma transversal que es requerido para todos los sectores, por ellos el PNUD ${ }^{11}$ establece una definición y especifica su impacto en la sociedad:

"Cuando se habla de género, se hace referencia a la existencia de un "sistema de relaciones sociales que involucra y afecta a hombres y mujeres" a la vez. "Género es el distinto significado social que tiene el hecho de ser mujer y hombre en una cultura determinada; el conjunto de características sociales, culturales, políticas, jurídicas y económicas asignadas socialmente en función del sexo de nacimiento. En la mayoría de las sociedades este sistema sexo-género ha desarrollado relaciones de desigualdad, exclusión y discriminación contra las mujeres en la mayor parte de las esferas de la vida. Esto se traduce en menos oportunidades, menor acceso y control de los recursos y una menor valoración y reconocimiento a sus actividades y a sí mismas." 12

Naciones Unidas (ONU) ha definido la política pública a través de la política social, la cual "es un instrumento que utilizan los gobiernos para regular y complementar las instituciones del mercado y las estructuras sociales" (ONU, 2007, Pág. 6). Es decir que esta va mucho más allá de plantear solo un espacio de acción, sino que termina siendo la implementación de un marco social que en algunos casos como lo define la ONU, son "servicios sociales como la educación, la salud, o la seguridad social. Sin embargo, la política social incluye mucho más: distribución, protección y justicia social.” (Ibídem)

\footnotetext{
${ }^{11}$ Programa de las Naciones Unidas para el Desarrollo.

12 (Programa de las Naciones Unidas para el Desarrollo - PNUD Argentina; AECID; Consejo Nacional de las Mujeres).
} 
Por lo anterior, cualquier Política Pública tiene unos componentes principales que son "los principios que la orientan (la ideología o argumentos que la sustentan); los instrumentos mediante los cuales se ejecuta (incluyendo aspectos de regulación, de financiamiento, y de mecanismos de prestación de las políticas) y los servicios o acciones principales que se llevan o deberían llevarse a cabo de acuerdo a los principios propuestos. ” (Ibídem).

De acuerdo con esto, Müller (Op. Cit. Pág. 56) planteó unos elementos de identificación de la política pública: "1. Substancia: Conjunto de medidas concretas que la conforman 2. Coerción: Decisiones o una forma de asignación de los recursos 3. Marco General de Acción: Parámetros no aislados para la ejecución 4. Receptores: Público (Individuo, grupos u organización) que son afectados por esta política 5. Metas: Objetivos para lograrse." En ese sentido y si bien los elementos de identificación no son iguales a los planteados por el autor, se determinan características esenciales que desde la academia se reflejan en las Naciones Unidas como ente internacional que garantiza los derechos humanos aconsejando sobre directrices que los Estados deben seguir:"1. Implicaciones del gobierno, 2. Percepción de los problemas, 3. Definición de objetivos y, 4. Procesos.” De acuerdo con la interacción de los anteriores, se puede plantear si existe o no una política pública, así mismo, como a través de actores sociales, se logra su implementación y si los destinatarios de ella la reciben conforme a se planteó o por el contrario están en contra de ello.

Se puede observar que autores internacionales han planteado la elaboración de políticas públicas en dos modelos, el primero llamado racional y planteado por H. Simons, "que consiste en recoger informaciones e investigar de forma sistemática con el objeto de identificar los problemas presentes o posibles. Definir todas las alternativas posibles para enfrentar cada problema. Hacer un análisis omnicomprensivo de todas las posibilidades alternativas y de sus consecuencias."(RUIZ, L., 2005). El segundo modelo llamado incremental, es planteado por Ch. Lindblom, el cual “consiste en la elaboración de las 
políticas y tiene como punto de partida la situación existente anteriormente, esta plantea sólo pequeños cambios o modificaciones de manera incremental.” (Ibídem).

Así mismo los enfoque teóricos sobre a quién va dirigido la política puede plantear diferencias, ejemplo de teorías centradas en la sociedad, o en el Estado o por último que terminan siendo una mixtura entre las anteriores. Por ello, la formulación de las políticas públicas suele estar dividas en ciertas etapas o pasos, Müller trazo un marco secuencial, desde la política pública cognitiva con el fin de realizar una estructura y una futura agenda política: “a) Identificación del problema (Programme identification). Proceso de percepción, definición, organización de estructuras, representación de intereses y definición de agenda. b) El desarrollo del programa (Programme development). Tratamiento del problema (formulación de propuestas de resolución y adquisición de una aprobación política). c) La puesta en marcha del programa (Programme implementation). Aplicación de las decisiones tomadas, d) Terminación del programa (Programme termination). Resolución del problema.” (Op. Cit., Pág. 58).

Pero por el desarrollo social del tema, otros autores han diseñado una estructura parecida basada en los modelos anteriormente mencionados: "a) Establecimiento de la agenda política. b) La definición de los problemas. c) La previsión. d) Establecimiento de objetivos. e) La selección de la opción.” (Müller, Óp. Cit. 67). Dentro del establecimiento de la agenda política termina siendo necesario, pues es el debate público del conjunto de problemas que se tienen y la intervención de las autoridades nacionales que regulan el tema. (Müller, Op. Cit., Pág. 66)

La claridad en los elementos permiten diseñar dicha política para evitar fracasos o errores que puedan llevar a daños o factores que afecten el problema que se está tratando de solucionar y las posibles mejoras que a futuro puedan tener, por tanto se plantea los siguientes: a) Oportunidad, b) Calidad, c) Transparencia y d) Apropiación social. 
Dentro de este diseño la ONU ha trazado la necesidad de un diagnóstico social para entender las necesidades de la población desde diferentes perspectivas, pues uno de los objetivos principales es "aumentar el bienestar de los ciudadanos desarrollar el capital humano, fomentar el empleo y mejorar la cohesión social." (Óp. Cit. Pág. 14 a 20). De la misma forma es necesario identificar las necesidades, los obstáculos, los riesgos en que incurre la población.

Se han planteado herramientas para que las políticas públicas puedan tener un mejor desarrollo y sea posible la apropiación tanto de los actores como de los receptores de ellas, dichas herramientas son como los incentivos, la construcción de capacidades, las herramientas simbólicas y la motivación a través del aprendizaje son algunas de ellas. A partir de ello, tanto la relación entre el Estado y la Sociedad puede mejorar por medio de la acción pública desarrollada por una política pública y como lo menciona Müller "se hace posible lo deseable", de las realidades complejas de cada ser humano o grupo social limitando pues "decodifica lo real para definir nuevos puntos de apoyo para actuar (territorialización) y recodificar lo real para definir modo operaciones que se puedan traducir en un programa de acción política (Relación Global - Sectorial) (Müller, Op. Cit., Pág. 74).

Lo anterior, de acuerdo a que desde el Referente Global-Sectorial de Müller, se proyecte por medio de un algoritmo operacional (que clasifica la información para realizar los cambios que los afectan) desde los "operadores intelectuales por medio de la necesidad y la modalidad de acción que se desee implementar por medio de la constatación de que ha cambiado” (Müller, Op. Cit. Pág., 77) en el entorno Periferia-Centro (Región-Nación), que codifican la información para que regrese desde la última descodificada, pues son los primeros constructores de referentes de Política Pública. 
En cuanto al enfoque de derechos en la política, la Organización de Estados Americanos (OEA) por medio del ISM plantea que "los derechos sociales, económicos, civiles, políticos y culturales son los pilares fundacionales sobre los cuales se construye una sociedad integrada e inclusiva. No son los derechos humanos meras declaraciones retóricas, sino el fundamento a partir y a través del cual se formulan e instrumentan las políticas públicas (...) Todas las metas de las políticas sociales están, por tanto, referenciadas a garantizar su más pleno ejercicio, atendiendo precisamente a las diferencias emergentes en el punto de partida” (Rossi, Julieta. 2013. Pág. 34)

Lo anterior, permite entonces plantear que es necesario el actuar del Estado para que se permita la eficacia de los derechos fundamentales de todas las poblaciones, por tanto la implementación de distintas "metodologías, marcos conceptuales, diseños institucionales y modalidades de la gestión pública a fin de mejorar las condiciones para el ejercicio efectivo y activo de los derechos por parte de sus titulares, promoviendo la participación social, el fortalecimiento de las capacidades de las personas, la producción y circulación de información relevante” (Rossi, Julieta. 2013).

Dentro del actuar del Estado, se hace necesario que los principios de igualdad y no discriminación sean fundamentales en su desarrollo, ejemplo en el caso de la igualdad la cual "se inviste como un ideal y un ideario, y es particularmente pertinente en contextos sociales, culturales, económicos y políticos asignados por desigualdades estructurales originadas en procesos históricos y modelos de desarrollo anclados en la economía de mercado" (Ibídem). 


\subsection{Instrumentos Internacionales y Nacionales de Política Pública con enfoque de Género.}

\subsection{1 Ámbito Internacional}

Por ello es importante resaltar los estudios internacionales que se han realizado en el campo de la equidad de género, y su influencia en la política pública. Naciones Unidas en el año 2014 presentó una guía (ONU, Junio, 2014) para moldear las formas de inclusión, esta desarrolla la importancia de la participación de la mujer a partir de las contribuciones que ella puede construir (legitimidad democrática, el buen gobierno y un desarrollo sostenible con la modificación de estereotipos). Pero lo anterior se ve mermado por los perjuicios desarrollados a lo largo de la historia, afectando la aplicación con la paralización de su progreso, dentro de estos encontramos:

- "Falta de apoyo de sus familiares, cónyuge y demás

- Maternidad precoz.

- Acoso, violencia y discriminación.

- Obstáculos relacionados con la desigualdad del orden socioeconómico.

- Estructura y cultura machista.

- Acceso restringido a diversos sectores.

- Falta de autoestima." (ONU, Junio, 2014)

Por lo anterior, las Naciones Unidas crearon una oficina que es la encargada de promover la igualdad de género y el empoderamiento de las mujeres, por medio del establecimiento de normas internacionales, el trabajo conjunto con los gobiernos y la sociedad civil.

Su enfoque se respalda en cinco áreas: "el incremento del liderazgo y de la participación de las mujeres; la eliminación de la violencia contra las mujeres; la participación de las 
mujeres en todos los procesos de paz y seguridad; el aumento del empoderamiento económico de las mujeres; y la incorporación de la igualdad de género como elemento central de la planificación del desarrollo y del presupuesto nacional” (Aguirrezabal, I. ONU, Pág. 5)

De acuerdo a lo planteado uno de los factores que más afecta la desigualdad de género es la inequidad social y por tanto se comporta como un desafío para la comunidad en general. Los avances que se presentan en el ámbito regional de cada grupo de países o dentro de cada uno de ellos como lo son "un cambio cultural notable, (...) mayor acceso de las mujeres a recursos, al prestigio y a la valorización de sus capacidades en la sociedad; la extensión del marco jurídico internacional plasmado en un fuerte compromiso regional; una mayor concienciación de la opinión pública sobre la desigualdad de género y sobre sus consecuencias en el desarrollo sostenible; así como un movimiento feminista pujante que, tras años de incidencia política, ha logrado introducir la agenda de género en los debates sobre la democracia representativa”. (Ibídem, Pág. 11)

Por ello, dentro de los distintos informes presentados se halló uno del año 2010, con el nombre de Informe de la dimensión humana de América Latina el cual comenta que se "en América Latina y el Caribe se encuentran diez de los quince países con mayor inequidad del mundo. El mayor impacto de esa inequidad social se produce en las mujeres, en las poblaciones indígenas y afrodescendientes, así como en los y las jóvenes (Ibídem, Pág. 15). Se analizó porque se planteó un nuevo modelo de democracia, en la donde la inclusión, la igualdad y la universalidad son el marco de la política a aplicar en las relaciones sociales de hombres y mujeres se basen en la igualdad y el enfoque de género resulta un requisito, compromiso y resultado.

A pesar de la brecha existente, según la OCDE en "Atlas of Gender and Development" de 2010, se estableció que la región ha avanzado de manera notable con relación a los 
derechos de ciudadanía de las mujeres, este progreso se relaciona "con el reconocimiento formal de los derechos de las mujeres, tanto en la armonización de su legislación al marco jurídico internacional, como en la adopción de políticas y programas orientados a cerrar las brechas de género y ampliar los derechos de las mujeres a la justicia, la toma de decisiones y los recursos”. (Ibídem, Pág. 16)

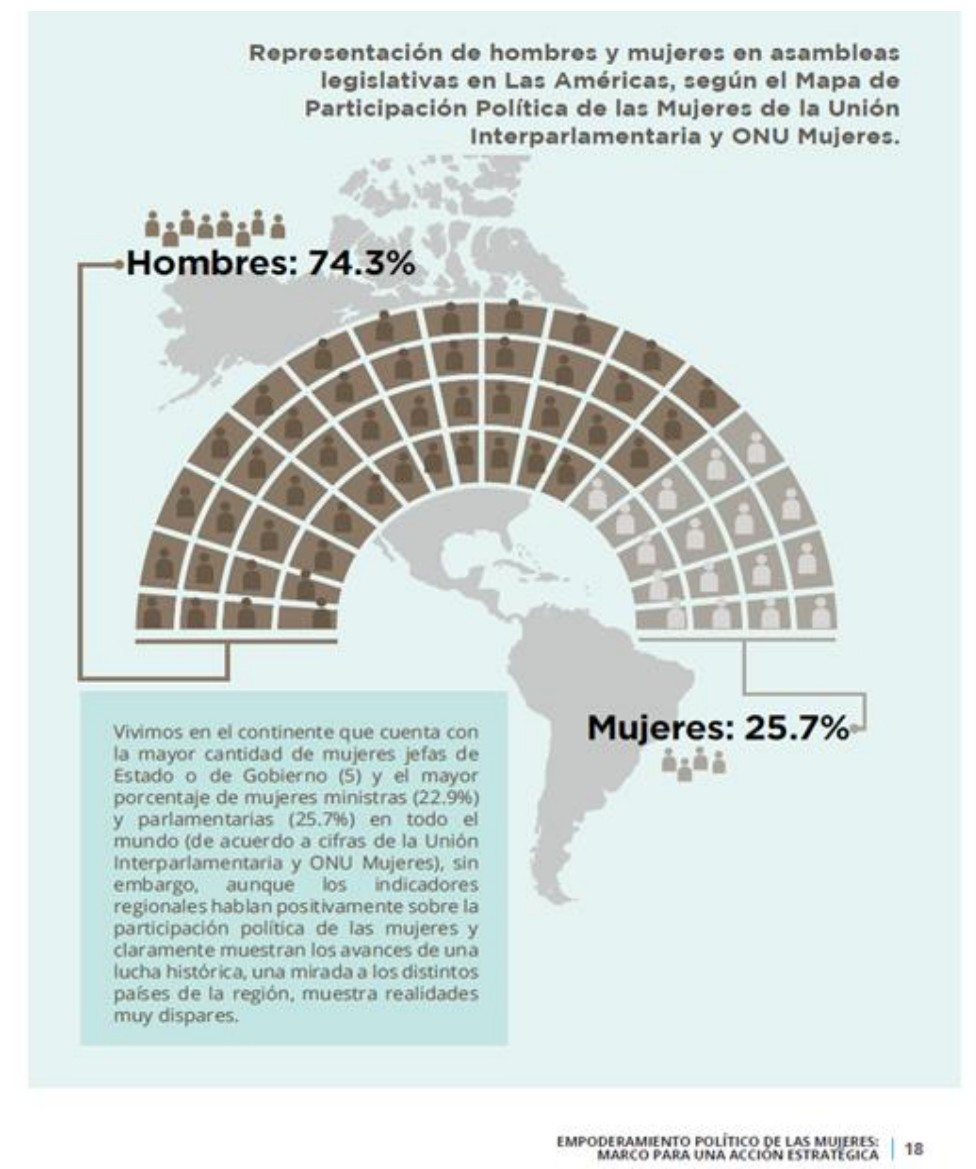

Gráfico 2. Representación de Hombres y Mujeres en Asambleas Legislativas en Latinoamérica.

(Naciones Unidas, 2014) 


\subsection{2 Ámbito en América Latina y el Caribe}

Dentro de este aparte, se encuentran las diversas normas que son desarrolladas a partir de la Convención Americana de Derechos Humanos:

- Convención Interamericana sobre la Concesión de los Derechos Políticos de la Mujer, de 1948, Artículo 1.

- Convención Americana de Derechos Humanos, de 1969, Artículo 23.

- Comisión Interamericana de Derechos Humanos.

- Convención Interamericana para Prevenir, Sancionar y Erradicar la Violencia Contra la Mujer (Convención de Belém do Pará), de 1994, señala en su artículo 4

- Carta Democrática Interamericana de 2001 reconoce que la democracia es indispensable para la estabilidad, la paz y el desarrollo de la región y que uno de los propósitos de la OEA consiste en promover y consolidar la democracia representativa dentro del respeto del principio de no intervención. Artículo 9.

- OEA - Comisión Interamericana de Mujeres (CIM)

- Banco Interamericano de Desarrollo- dispone también de una importante iniciativa para promover la representación y el liderazgo de las mujeres a través del Programa de Apoyo al Liderazgo y Representación de la Mujer (PROLID).

- Las Conferencias Regionales de la Mujer en América Latina y el Caribe.

- La X Conferencia Regional de la Mujer de América Latina y el Caribe, o Consenso de Quito.

- La XI Conferencia Regional sobre la mujer de América Latina y el Caribe, o Consenso de Brasilia, se llevó a cabo entre el 13 y el 16 de julio de 2010 en Brasilia (Brasil).

- En 2013, la región logra un avance importante con la adopción del Consenso de Montevideo sobre la Población y el Desarrollo, en la primera Conferencia 
Regional sobre Población y Desarrollo en América Latina y el Caribe, llevada a cabo entre el 12 y el 15 de agosto de 2013.

- XII Conferencia Regional sobre la mujer de América Latina y el Caribe, celebrada en Santo Domingo (República Dominicana) entre el 14 y el 18 de octubre de 2013, adoptó el Consenso de Santo Domingo para avanzar en la igualdad de género.

En cuanto al tema, de representación y participación de la mujer en la toma de sus decisiones se encuentra desproporcionada a la cantidad poblacional que representa, siendo el cincuenta por ciento (50\%) o más de la población. “(...) la participación de las mujeres aporta ideas y formas de actuar diferentes - o, por lo menos, complementarias a las de los hombres - en el proceso de toma de decisiones ante los retos que plantea la sociedad, dados los distintos roles y experiencias de mujeres y hombres que derivan de aprendizajes diferenciados." Por ello la implementación de nuevas formas de tomar decisiones comenzando con un cambio de vocabulario o modificar patrones culturales permite transformar esquemas mentales y sociales que son las tradiciones y nos han llevado por muchos siglos a factores de discriminación.

La participación política de las mujeres en los gobiernos locales o subnacionales son determinantes en el funcionamiento de un país, pues estas entidades desde un punto de vista económico, social y demográfico permiten un aproximación de donde deben partir las políticas públicas que deben desplegar para mejorar las condiciones de la población.

Según los datos de la CEPAL de 2011 "sitúan la media de mujeres alcaldesas en la región latinoamericana en el 10,2\%, con sólo cinco países de la región que superan el $20 \%$. Datos más recientes ratifican que únicamente un $10 \%$ de mujeres llega a ser titular de gobiernos locales, si bien el número de concejalas se ha ido incrementado a lo largo de la 
década y en 2012 alcanza el 25\%.39 En 2012, según el PNUD, sólo dos países superan el $20 \%$ de alcaldesas, Bolivia con 22\% y Uruguay con 25,3\%" (Página 39).

De acuerdo a los datos presentados de la cantidad de las mujeres que se encuentran en la rama ejecutiva en América "cuenta con el mayor número de mujeres Jefas de Estado o Jefas de Gobierno; cinco a fecha de junio de 2014. Hasta abril de 2014, había seis mujeres ejerciendo la jefatura del Gobierno o del Estado en la región: Cristina Fernández, en Argentina, Dilma Rousseff, en Brasil, Laura Chinchilla Miranda, en Costa Rica, Portia Simpson-Miller, en Jamaica, Kamla Persad-Bissessar, en Trinidad y Tobago y Michelle Bachelet, en Chile. El dato es relevante, si tenemos en cuenta que, a nivel mundial, hay un total de dieciocho mujeres como titulares del Ejecutivo;" (Ibídem, Pág. 39).

La ONU, en su enfoque dedicado a la mujer ha establecido unas Estrategias de Intervención:

- Crear puentes, coordinar y liderar.

- Generar conocimiento

- Brindar asistencia técnica

- Desarrollar y fortalecer capacidades

Y los objetivos estratégicos son:

- Promover la democracia paritaria: medidas afirmativas.

- Integrar la perspectiva de género en políticas, acciones e instituciones.

- Fortalecer liderazgos de mujeres

- Promover partidos políticos que favorezcan la igualdad sustantiva entre hombres y mujeres

- Combatir la discriminación, los estereotipos sexistas y la violencia 
Todo lo anterior, representa la adopción de un paquete global y dinámico con normativas, políticas y estándares qué garanticen la igualdad de género.

La Comisión Económica para América Latina y el Caribe (CEPAL) identificó que materia de mujeres, se busca es la "justicia distributiva, de reconocimiento y de representación, fortaleciendo los logros de las mujeres en las tres áreas de preocupación planteadas: (...) autonomía física, económica y política”. (Octubre, 2012, Pág. 3) por ello se diseñó una matriz que deba considera las distintas fases del ciclo de la política, de modo que el análisis se realiza en la identificación y definición de los problemas públicos, la formulación, la implementación, y la evaluación (control y vigilancia) y el seguimiento de la política.

Esta matriz sugiere lo planteado por Fraser en 1996 sobre evaluar las políticas públicas en su capacidad para enfrentar "la injusticia socioeconómica, expresada en la distribución injusta de bienes y recursos; las injusticias legales y culturales que se manifiestan en el dominio cultural y la injusticia en la representación, referida la jurisdicción del Estado y a las reglas que organizan la confrontación.” (Benaventer. M, Valdes, A. Pág. 5) 


\begin{tabular}{ll}
\hline Fases del ciclo de la política pública & Puntos a considerar en cada fase \\
\hline A. Identificación y definición de los & A.1 Marcos de sentido \\
problemas públicos a que responde & A.2 Identificación del problema \\
la política. & A.3 Identificación de injusticias de género \\
B. Formulación/Diseño & B.1 Objetivo de la acción estatal \\
& B.2 Marco normativo \\
& B.3 Marco político social \\
C. Implementación & C.1 Descripción general \\
& C.2 Transversalidad \\
& C.3 Relación sistema político/ sistema \\
& administrativo/ sociedad civil \\
& C.4 Información y difusión \\
& C.5 Sostenibilidad \\
& C.6 Desarrollo de competencias, capacidades, \\
habilidades \\
D.1 Monitoreo \\
D.2 Producción de información \\
D. Evaluación /Control y vigilancia Resultados respecto de los objetivos de la \\
política \\
D.4 Avances en justica para las mujeres \\
D.5 Temas pendientes \\
\hline
\end{tabular}

6

Gráfico 3. Diseño de Políticas Públicas.

(CEPAL, 2014)

\subsection{3 Ámbito Nacional}

Lo planteado por Jolly (2002, Pág. 9) desde el análisis de la descentralización, termina reuniendo lo trazado por Müller, pues aquella es la aplicación de un proceso híbrido de jerarquización del poder que se realiza de dos formas: "lógica territorial” (horizontal) y "lógica sectorial” (vertical) de regulación, es la afirmación que las políticas públicas locales y el juego político local que les está ligado desde lo nacional, "la construcción de un espacio de mediación", donde todas las políticas están interactuando, pues se crean diversas estrategias desde distintos ámbitos locales para una proyección global como lo llamaría Müller, es decir, nacional. 
Dentro del marco normativo, siendo la base la Constitución Política, está desarrolló los artículos 1, 2, 13, 43 como garantías para la mujer y el hombre sobre la base de la igualdad en el Estado Social de Derecho. Esto permitió que a partir del siguiente orden normativo, se impulsara la política pública de protección de la mujer por medio de acciones afirmativas.

Ley 581 de 2000, conocida como la Ley de Cuotas, en la cual se instaura que la participación femenina en los niveles decisorio de la Administración Pública debe ser en un porcentaje del treinta por ciento $(30 \%)$.

Ley 823 de 2003, siendo uno de los aporte más importantes dentro de ella, la obligación impuesta a las entidades territoriales de implementar dentro de los planes de desarrollo la estimulación y promoción a la mujer.

Ley 1009 de 2006 con la cual se crea el Observatorio de Asuntos de Género y se estableció que las entidades nacionales deben suministrar cierta información.

Ley 1257 de 2008 declaró que la vida de las mujeres debe ser libre de violencia, y es necesaria la adopción de políticas públicas necesarias para que se proceda a la realización del derecho y la promoción del cambio cultural. Por ello la Ley declara que violencia contra la mujer es:

“cualquier acción u omisión, que le cause muerte, daño o sufrimiento físico, sexual, psicológico, económico o patrimonial por su condición de mujer, así como las amenazas de tales actos, la coacción o la privación arbitraria de la libertad, bien sea que se presente en el ámbito público o en el privado. Para efectos de la presente ley, y de conformidad con lo estipulado en los Planes de Acción de las Conferencias de Viena, Cairo y Beijing, por violencia económica, se entiende cualquier acción u omisión orientada al abuso económico, el control abusivo de las finanzas, recompensas o castigos monetarios a las mujeres por razón de su condición social, económica o política. Esta forma de violencia 
puede consolidarse en las relaciones de pareja, familiares, en las laborales o en las económicas.

En Colombia, estas políticas se fijaron por la Alta Consejería Presidencial para la Equidad de la Mujeres en los "Lineamientos de la Política Pública Nacional de Equidad de Género para las Mujeres" (Colombia, 2012), en su construcción participaron distintos redes y organizaciones de mujeres y con acompañamientos de la comunidad internacional (ACNUR, AECID, GIZ, USAID, PNUD), esto fue el desarrollo del Artículo 177 de la Ley 1450 de 2011, que corresponde al Plan Nacional de Desarrollo. En el caso colombiano sus ejes son:

“-Autonomía económica e igualdad en la esfera laboral y del cuidado

- Construcción de paz

- Participación en los procesos de toma de decisiones y en las esferas de poder • Salud integral y derechos sexuales y reproductivos

- Educación de calidad con enfoque diferencial y acceso de las mujeres a las Tecnologías de la Información y las Comunicaciones

- Territorio, hábitat y medio ambiente

-Gestión pública, desarrollo institucional, y transformación cultural y comunicación como ejes transversales de la Política

- Los lineamientos del Plan integral para garantizar a las mujeres una vida libre de violencia."

A partir de estos, se desarrolló el documento para orientar a las entidades territoriales, el cual fue desarrollado con la participación de diversos sectores de la población femenina para así establecer dentro del Plan Nacional de Desarrollo 2010-2014 como se puede contribuir al progreso en el goce efectivo de los derechos de las mujeres. Lo anterior sirvió como base fundamental para el documento CONPES Social 161 de Equidad de Género del 
12 de Marzo del 2013, el cual tiene uno de los desafíos más grandes, pues a partir de las regiones, departamentos y municipios se busca fortalecer el empoderamiento de la mujer como sujeto de derechos y no solo de obligaciones, siendo la Alta Consejería Presidencial para la Equidad de la Mujer un órgano de asesoría y asistencia para las entidades territoriales en la implementación del CONPES Social 161 del 2013.

La estrategia de territorialización es entendida como "el conjunto de acciones que se llevan a cabo para su implementación integral bajo principios de coordinación, concurrencia, subsidiariedad y complementariedad entre los ámbitos político administrativos nacional y territoriales, en armonía con las acciones de género que se desarrollan desde lo departamental y lo municipal." (Alta Consejería Presidencial para la Equidad de la Mujer, Pág. 18). En consecuencia como cumplimiento de los Objetivos de Desarrollo del Milenio, propuesto por la Asamblea General de las Naciones Unidas.

A partir de lo descrito en la Ley 1551 de 2012, la cual modernizó la organización y el funcionamiento de los municipios, una de las funciones impuestas es "Elaborar los planes de desarrollo municipal (incluyendo estrategias y políticas dirigidas al respeto y garantía de los derechos humanos y el DIH).", siendo así uno de las metodologías aplicadas por el Estado para dar cumplimiento a los Objetivos de Desarrollo del Milenio.

De esta manera, se busca que transversalmente las entidades públicas utilicen la construcción de paz y la transformación cultural como formas de protección al derecho a la igualdad de forma real y efectiva, por medio del enfoque de género tal como lo planea la sentencia C-804 de 2006. Por ello se constituye de forma relevante que para el alcance de este eje es necesario la "transformación de los imaginarios culturales, como el fortalecimiento de la gestión pública y el desarrollo institucional que los dinamice" (Pág. 21) 
Dentro del desarrollo internacional que se ha dado para la protección de la mujer, especialmente en materia de política pública, la Asamblea General de las Naciones Unidas adoptó en el año 2000 la Declaración del Milenio ${ }^{13}$ [1], "una agenda ambiciosa para reducir la pobreza, sus causas y manifestaciones, así como los Objetivos del Desarrollo del Milenio (ODM). El ODM3 se propone "promover la igualdad entre los sexos y el empoderamiento de la mujer. Igualdad entre los géneros que implica también una representación igual en la vida pública y política” (...) Pág. 22

La resolución dentro de la cual se establecieron los ODM sobre mujeres y participación política (A/Res/66/130), reitera la preocupación por la marginalización a que siguen sometidas millones de mujeres en los procesos de toma de decisiones en todos los niveles, pues, este termina siendo la base fundamental para la igualdad, el desarrollo sostenible, la paz y la democracia.

Hacia el año 2013, El Ministerio de Relaciones Exteriores de Colombia, en la Dirección de Asuntos Económicos Sociales y Ambientales, rindió informe a la CEPAL sobre el cumplimiento y los desafíos restantes en cabeza del Estado, haciendo principal énfasis a la aplicación del enfoque diferencial y su transversalidad en la política pública planteada. Lo anterior, hace referencia a lo mencionado dentro de LOS LINEAMIENTOS DE LA POLÍTICA PÚBLICA NACIONAL DE EQUIDAD DE GÉNERO PARA LAS MUJERES Y DEL PLAN INTEGRAL PARA GARANTIZAR UNA VIDA LIBRE DE VIOLENCIAS, así como dentro del documento CONPES 161 de EQUIDAD DE GÉNERO PARA LAS MUJERES.

${ }^{13}$ Declaración del Milenio de la Asamblea General (A/RES/55/2) de 2000, ODM3. 
Cuadro 1. Comparación de los acuerdos del Consenso de Brasilia y los ejes de la Política de Equidad de Género para las Mujeres en Colombia

\begin{tabular}{|c|c|}
\hline $\begin{array}{l}\text { Principales Acuerdos del Consenso de } \\
\text { Brasilia }\end{array}$ & $\begin{array}{l}\text { Principales ejes/estrategias establecidos } \\
\text { en el CONPES }\end{array}$ \\
\hline $\begin{array}{l}\text { Conquistar una mayor autonomía } \\
\text { económica e igualdad en la esfera laboral }\end{array}$ & $\begin{array}{l}\text { El segundo eje de la Política es el de } \\
\text { garantizar la autonomía económica de las } \\
\text { mujeres y potenciar la conciliación de la vida } \\
\text { laboral y doméstica. }\end{array}$ \\
\hline Fortalecer la ciud & $\begin{array}{l}\text { La Política destaca su carácter transversal } \\
\text { en el resto de políticas públicas. }\end{array}$ \\
\hline $\begin{array}{l}\text { Ampliar la participación de las mujeres en } \\
\text { los procesos de toma de decisiones y en } \\
\text { las esferas de poder }\end{array}$ & $\begin{array}{l}\text { eje se refiere a la participación de } \\
\text { es en instancias de poder y toma de } \\
\text { s. }\end{array}$ \\
\hline $\begin{array}{l}\text { Enfrentar todas las formas de violenc } \\
\text { contra las mujeres }\end{array}$ & $\begin{array}{l}\text { El sexto eje desarrolla el plan integral para } \\
\text { garantizar a las mujeres una vida libre de } \\
\text { violencias }\end{array}$ \\
\hline $\begin{array}{l}\text { Facilitar el acceso a las mujeres a las } \\
\text { nuevas tecnologías y promover medios de } \\
\text { comunicación igualitarios, democráticos y } \\
\text { no discriminatorios }\end{array}$ & $\begin{array}{l}\text { El documento CONPES } 161 \text { en su anexo } 5 \\
\text { describe los retos del Ministerio de las } \\
\text { Tecnologías y la Información para el } \\
\text { desarrollo de procesos de formación } \\
\text { orientados a la generación de competencias } \\
\text { para el uso y apropiación de las TIC por parte } \\
\text { de las mujeres en los próximos cuatro años. }\end{array}$ \\
\hline r la salu & $\begin{array}{l}\text { El cuarto y el quinto eje se ocupan del } \\
\text { enfoque diferencial de derechos en el sistema } \\
\text { de salud y educación respectivamente. }\end{array}$ \\
\hline
\end{tabular}

Gráfico 4. Comparación de los acuerdos del Consenso de Brasilia y los ejes de la política de Equidad de Género para las mujeres en Colombia.

(MINISTERIO DE RELACIONES EXTERIORES, 2013)

Esto permite analizar si la implementación que inició en el año 2013 de esta política pública se ha visto reflejada en los entes territoriales, especialmente en el objeto de análisis, el cual es el Meta.

\subsection{Aplicación y verificación de los instrumentos en el Departamento del Meta.}

La ordenanza departamental No. 786 de 2012, aprobó la Política Pública de Equidad de Género para las Mujeres del Meta (PPEGMM) 2012-2023, en la cual se plantearon retos para todos los actores sociales (sociedad, instituciones y colectivos) con el propósito de revitalizar y dar una aplicación efectiva al Estado Social de Derecho, base de nuestro 
Sistema Político, con el fin de disminuir y llevar a la terminación toda forma de inequidad y discriminación de género.

La política pública ha sido estructurada en siete (7) ejes:

1. Derecho a una vida libre de violencias

2. Autonomía y empoderamiento económico de las mujeres

3. Participación y representación política con equidad de género

4. Salud integral para las mujeres

5. Educación con equidad de género

6. Construcción de paz y justicia de género

7. Hábitat, vivienda, medio ambiente y acceso a la tierra

Estos ejes son armonizados junto con el plan departamental de desarrollo 2012-2015 "Juntos Construyendo Sueños y Realidades" que se realizó con la ayuda de organizaciones de mujeres ("600 mujeres de los 29 municipios del departamento mediante encuentros subregionales y 9 encuentros sectoriales" (Enero, 2014, Pág. 5).

Se buscó que la Secretaría de la Mujer y la Equidad de Género realizará el análisis del cumplimiento de los acordado dentro PPEGMM. La implementación de programas y subprogramas llevados a los distintos municipios durante este transcurso de tiempo, permitió que programas de capacitación sobre derechos de la mujer fueran recibidos por mujeres: víctimas de desplazamiento, víctimas, afrodescendientes, indígenas, campesinas, jóvenes, líderes, madres comunitarias, y distintas organizaciones en el Departamento, así como realizar monitoreo sobre los distintos tipos de violencia en la mujeres que derivan en la discriminación de ella y la inestabilidad del Estado Social de Derecho. 
Por lo anterior, se destacó en el caso de las monitorias realizadas a las Comisarías de Familia la siguiente información:

- "En la región del Ariari se redujo los casos de violencia de 2012 a 2013 en un $28.49 \%$

- En la región del Piedemonte se redujo los casos de violencia de 2012 a 2013 en un $38.53 \%$

- En la región del Río Meta se redujo los casos de violencia de 2012 a 2013 en un 50\%" (Ibídem.)

Estos valores inciden de manera directa no solo en el entendido de las dificultades que se presentan con las mujeres, sino de aquellos que conviven con ellas y se ven afectados por estos factores, los cuales son los hijos, sobrinos o hermanos. Por tanto, se permite establecer una mejor calidad de vida para menores en sentido de salud (física y mental) y desarrollo social, así como un incentivo para que la capacidad laboral de ellas no se vea reducida.

En razón a lo antepuesto, las acciones nacionales deben incidir de forma multisectorial, incluyendo todo lo que necesita un ser humano para tener una vida digna, es decir, reducir el índice de necesidades básicas insatisfechas (NBI) en la población del departamento.

Para la promoción del eje tercero "Participación y Representación Política Con Equidad De Género" se formó una escuela de formación de política y liderazgo, del cual se graduaron 553 mujeres, se capacitaron 100 mujeres en Gerencia Política, se suscribió el convenio de asociación No. 0725 de 2013 con la Universidad Santo Tomás con la participación de 553 mujeres, utilización de herramienta de 6000 ejemplares de documentos publicados. 
Para realizar todo lo anterior se establecieron unos principios sobre los cuales se realiza el ejercicio de transversalización:

- Participación crítica

- Participación organizada

- Participación creativa

- Participación activa

- Participación equitativa

Dentro del marco normativo que se desarrolla, existe una política pública para inclusión de la mujer, el ámbito de protección constitucional y su desarrollo legal, permite plantear preguntas entorno a la efectividad de las mismas y su aplicación en espacios locales, haciendo uso entonces de la fase final de la matriz de análisis planteada por Fraser con anterioridad.

Con el desarrollo del CONPES 161 para el fortalecimiento de la mujer, se puede percibir la aplicación de estrategias para solucionar una problemática que viene de tiempo atrás, organizando entonces la acción pública planteada por Müller a través del referente globalsectorial. En el plano colombiano el concepto utilizado es la territorialización, siendo un desarrollo híbrido, pues se aplican políticas públicas horizontales (descentralización) y verticales (Nación-Entes Territoriales). En estas se construyen los referentes de "codificar y descodificar" las realidades latentes en cada municipio y sus necesidades a un sector más amplio como lo es la Nación. Por tanto los actores sociales replantean la relación del Estado y la sociedad, teniendo aquellos un papel más activo dentro de esta.

En el departamento, su territorialización o referente global-sectorial permitió analizar si las dimensiones nacionales podrían llegar a plantear una solución o si era necesario la intervención el ámbito local, demostrando así que es necesario primero la intervención de dimensiones (de poder e intelectual) o sectores de la sociedad para tener un desarrollo 
armónico en su planeación. Por ello, la intervención de 600 mujeres desde una dimensión de poder (líderes, profesionales, administradoras) mejoró la construcción de la imagen referente para la política pública del departamento, no obstante, este margen poblacional no puede ser definitivo, pues la población de mujeres del Departamento aproximada al año 2015 asciende a 430.000 .

Lo anterior, permite decir que se sigue con un margen de discriminación, la influencia en la toma de decisiones que afecten a las mujeres no se ven permeadas por la información primaria de estos sujetos de protección especial. 


\section{CONCLUSIONES}

La praxis de la democracia a lo largo de la historia política, ha sido un tema de amplia discusión, esencialmente para indagar por la materialización de la democracia participativa y deliberativa de la sociedad civil, y, en especial de los grupos o poblaciones tradicionalmente vulnerados. En ese orden de ideas, los teóricos que han estudiado la democracia y especialmente la liberal que caracteriza nuestro sistema político Colombiano, coinciden en la realización de algunos ejes para la ejecución efectiva de la democracia participativa, tales como las actuaciones de los movimientos sociales, su comunicación efectiva con las instituciones que los representan y su influjo en las decisiones que eventualmente podrían afectarlos.

Desde esa lógica, es un requisito imprescindible que los conocimientos y experiencias de vida del grupo poblacional de Mujeres del Departamento del Meta puedan apropiarse y concretarse en las políticas públicas que se elaboren con el cometido de resolver sus problemáticas como grupo social minoritario. La incorporación de tales conocimientos y experiencias a futuras políticas públicas, consigue que un conjunto de organizaciones, redes y grupos sociales que se han integrado para trabajar mancomunadamente en la reivindicación de los derechos y garantías en favor de la mujer, participen de manera real en las discusiones democráticas territoriales.

Asimismo, se consigue que la democracia deliberativa y participativa se active y cumpla su finalidad dentro del sistema político colombiano, mucho más cuando su accionar se da dentro del sector descentralizado de gobierno, para que a través de los planes de desarrollo, se proyecten políticas públicas particulares para grupos minoritarios o tradicionalmente 
excluidos, como el de las Mujeres en el Departamento del Meta. La deliberación y participación debe ser del grupo de mujeres que luchan por el reconocimiento de sus necesidades en conjunto con sus representantes, quienes concretaran dichas necesidades a través de este tipo de manifestaciones legales y gubernamentales como lo son las políticas públicas direccionadas a su bienestar.

Ahora bien, dicha comunicación e interrelación, se encuentra íntimamente ligada a la eficacia, legitimidad y estabilidad de la gobernabilidad y su relación con el ejercicio del poder político para la correcta participación directa de los ciudadanos, puesto que en términos de Habermas, solo así se permite la protección y garantía de sujetos en igualdad de condiciones y cuyas decisiones podrían ser comunes a todos.

Esta situación hace que exista una relación entre lo que se ha denominado como lo públicoentendido como el Estado- y la sociedad civil en ejercicio de la participación democrática de la búsqueda de condiciones y estándares mínimos que permitan la realización y efectividad del estado social de derecho. Dicha situación generará la efectiva consolidación de la democracia en la medida en que las organizaciones civiles en ejercicio de su poder de participación se constituyan en veedores de las decisiones del Estado, especialmente sobre temas que les afecten directamente para que logren incidir en las actuaciones que están mal o no encaminadas a lograr el bien común, no solo del grupo en particular sino de la sociedad en general.

Desde el concepto de democracia y específicamente la deliberativa y participativa, la finalidad es que los movimientos sociales materialicen sus derechos, para la consolidación de la Democracia y la continúa transformación de la sociedad, por eso es trascendental la articulación directa de los movimientos con los mecanismos estatales establecidos, con el fin de garantizar efectivamente la transversalidad y el pluralismo. 
A partir de ello, se debe tener en cuenta el papel del ciudadano, especialmente en lo que concierne a los grupos minoritarios tradicionalmente excluidos, y la preponderancia de los mismos en el desarrollo de las políticas públicas. Por esta razón, es necesario establecer un modelo democrático que propenda por la integración del Estado y la sociedad, que garantice un sistema dinámico a través de la inclusión, el pluralismo y las reivindicaciones socioeconómicas con el fin de hacer efectiva la implementación de sus componentes.

Así, al hablar de enfoque de género surge una cohesión de intereses comunes, para la visibilización y la influencia por medio de movimientos para el planteamiento de políticas sectoriales de acuerdo a sus necesidades. En diferentes contextos se han perfilado los movimientos sociales de mujeres como actores sociales colectivos que buscan mejorar y posicionar sus derechos e intereses de género. El debate para el reconocimiento de estos derechos y su ampliación, se ha dado a partir de la deliberación y la participación, por lo cual, es importante contar con dicha capacidad desde la esfera pública, mediante la participación real de las mujeres como fuente de cambio significativo encaminado a eliminar la desigualdad y la exclusión, teniendo como base la estructuración de nuevas concepciones políticas, culturales, sociales y económicas.

Es en este sentido, cobra relevancia que la participación real de las mujeres se vea reflejada en el marco de la elaboración de la política pública, por lo cual es necesario que ésta adecúe su planeación acorde al contexto en que aquellas se desenvuelven. Esto determinará finalmente la aplicación efectiva a partir de experiencias y enfoques específicos, para que se vivifique la verdadera problemática como uno de los elementos esenciales en la discusión sobre política.

De igual forma, es necesario que la estrategia para el fortalecimiento de la política pública sea aplicada a través de lo que se propone desde la teoría, con el sistema híbrido que corresponde a lo horizontal y lo vertical, es decir que se articulen los lineamientos 
nacionales con los instrumentos locales con el fin de que exista un desarrollo armónico en su planeación.

Es por esto, que la Creación del CONPES 161 de 2013 y el apoyo ofrecido por la Alta Consejería Presidencial para la Equidad de la Mujer, como consecuencia del Acuerdo de Basilea, se hizo necesario la aplicación de la estrategia de territorialización desde la perspectiva del enfoque de género, esto obedeciendo a su vez a lo planteado por la Asamblea General de las Naciones Unidas en los Objetivos de Desarrollo del Milenio, en la integración de los entes territoriales a toma de las decisiones.

La promoción en la igualdad y el empoderamiento de las mujeres, evitando la marginalización, se hizo efectiva de forma parcial en el caso del Departamento del Meta (Ordenanza 786 de 2012), al crearse una política exacta (con elementos de oportunidad, calidad, transparencia y apropiación social) para superar las condiciones de marginalidad y con ayuda de esta misma población.

Aunque los resultados extraídos son fragmentos del desarrollo total de esta política, la cual finalizará en el año 2016, se ve un reflejo de avance en este sector con la participación pequeña de las mujeres (600 de una población total de 430.000 aproximado, según el censo del año 2005). Por tanto, se hace necesario ahondar e incentivar no solo a la población adulta, sino desde la infancia para que los programas que se planteen no sólo sean de conocimiento de sus derechos, sino de los diversos mecanismos para accionar al Estado pero desde una perspectiva preventiva y no solo de reparación.

Para poder realizar este ejercicio, es necesario contar con las herramientas básicas de conocimiento de derechos y obligaciones por parte de los ciudadanos, analizando que esta entrega de información debe ser procesada dependiendo del sector y la población específica pues las tradiciones y el imaginario cultural permiten la dinamización del ente territorial. 
Por tanto, es supremamente importante para todas las mujeres del departamento del Meta que tienen una cantidad de experiencias de inequidad, opresión patriarcal, violencia y desplazamiento, contar con herramientas teóricas de leyes, decretos, metodologías de acción porque como mujeres pueden replicarlo en todas las redes que hacen parte. Esas redes y organizaciones que se están fortaleciendo en el departamento, así como la creación de la Secretaría Departamental de Equidad y Género son fundamentales para hacer grandes transformaciones en el empoderamiento de la política pública para las mujeres.

La mayoría de mujeres han manifestado tanto la importancia de conocer que existen mecanismos de defensa de sus derechos, como la de manifestar desde su propia experiencia de violencias y discriminaciones vividas, el cambio que implica para cada una saber que lo que les ocurre está lejos de ser correcto, de "ser natural" y comprender que los cambios en dichas situaciones empieza también por ellas mismas. Adicionalmente, se resalta con esto la necesidad de las mujeres de ser escuchadas, de poder contarle a otras sus historias de violencias, abandonos, luchas y resistencias.

Asimismo, han demostrado su capacidad creativa cuando trabajan juntas, tal como se hizo evidente el 25 de Noviembre de 2013 en el marco de la conmemoración del día internacional de la eliminación de la violencia contra la mujer, donde se demostró en 20 municipios del Departamento del Meta (Acacías, Cabuyaro, Cubarral, Cumaral, El Castillo, El Dorado, Fuente de Oro, Granada, Guamal, Lejanías, Mesetas, Puerto Gaitan, Puerto Lleras, Puerto López, Restrepo, San Carlos de Guaroa, San Juan de Arama, San Martín y Villavicencio), las inmensas posibilidades de articulación entre ellas, y sobre todo la capacidad creativa para posicionar el tema de sus derechos.

Las diferentes actividades lúdicas programadas y la gran marcha departamental, por las calles de cada uno de los veinte municipios enunciados, no sólo facilitó la participación de 
las mujeres, sino que instaló y posicionó el tema del enfoque diferencial de género en los diferentes municipios, respaldó a las organizaciones de mujeres en sus reivindicaciones cotidianas y generó la seguridad en muchas, de que ya sus problemas no estaban olvidados, dada la distancia de sus municipios con la capital del Departamento del Meta.

Todo lo anterior, exige mantener el impulso que ha dado la creación tanto de la política pública como de la Secretaría Departamental de la Mujer, para lo cual es fundamental hacer partícipes de los futuros lineamientos de política pública para mujeres, a las nacientes propuestas de las mujeres en el nivel municipal, y fortalecer los escenarios de deliberación con las redes de mujeres ya existentes.

Para tal cometido, hay que vincular cada vez más a las autoridades municipales en los procesos relacionados con el ejercicio y garantía de los derechos de las mujeres, puesto que la experiencia mostró como en los municipios en donde dichas autoridades estuvieron más involucradas, las mujeres lograron mayor incidencia en sus eventos conmemorativos del 25 de noviembre y mayor escucha a sus diferentes propuestas.

Finalmente, es evidente para la construcción de una política pública efectiva para las mujeres del Departamento del Meta, la necesaria participación y trabajo conjunto entre instituciones estatales y la academia, fortaleciendo desde el quehacer y responsabilidad de cada institución en la sociedad, los liderazgos de las mujeres, y las posibilidades de que a través de los mismos, se mejoren sus condiciones. Con ello, se materializa la participación activa y directa de la sociedad civil en la planeación, elaboración y ejecución de las políticas públicas con enfoque de género, como un mecanismo real de inclusión social en el Departamento del Meta. 


\section{REFERENCIAS BIBLIOGRÁFICAS}

Alberti Giorgio y Villena José. 2014. Movimientos e instituciones y la calidad de la democracia. Análisis de casos en América Latina y la Unión Europea. Pág. 32-33. Recuperado de: www.octaedro.com/downloadf.asp?m=16053.pdf

Alcaldía de Bogotá. 1994. Ley 134 de 1994. Exposición de motivos de la Ley que regula los Mecanismos de participación ciudadana. Recuperado de: http://www.alcaldiabogota.gov.co/sisjur/normas/Norma1.jsp?i=7383\#0

Alfama Eva, Neus Miró, Marc Martí, Laura Giménez, Anna Obradors, Robert González (IGOP- UAB). Género y movimientos sociales: la participación de las mujeres en la Plataforma en Defensa del Ebro.VII Congreso Español de Ciencia Política y de la Administración: Democracia y Buen Gobierno. 2009. Pág. 2 -12. Recuperado de: http://aprendeenlinea.udea.edu.co/lms/moodle/file.php/180/Genero_y_Movimientos_social es.pdf

Amenta, Edwin y Neal Caren. 2004. The Legislative, Organizational, and Beneficiary Consequences of State-oriented Challengers. En The Blackwell Companion to Social Movements, editado por David Snow, Sara A. Soule y Hanspeter Kriesi, 461-488. Oxford: Blackwell Publishing. Recuperado de: http://www.socsci.uci.edu/ ea3/Amentaetal.ars.2010.pdf

Alta Consejería Presidencial para la equidad de la mujer. 2012. Lineamientos de la Política Pública Nacional de Equidad de Género para las Mujeres. Bogotá, Colombia. Recuperado 
de: http://www.equidadmujer.gov.co/Documents/Lineamientos-politica-publica-equidadde-genero.pdf

Alta Consejería Presidencial Para La Equidad De La Mujer. 2014. Orientaciones Para La Territorialización De La Política Pública Nacional De Equidad De Género Para Las Mujeres. Marta L. Tamayo Rincón. Colombia.

Ayala Sánchez, A. (2012). Democracia en la era digital. México: Universidad Nacional Autónoma de México.

Benavente R., María C., Valdés B., Alejandra. Políticas Públicas Para La Igualdad De Género. 2014. Un Aporte A La Autonomía De Las Mujeres. Comisión Económica Para América Latina Y El Caribe (CEPAL). Santiago De Chile.

Boron, Atilio A. y Lechini, Gladys. 2006. Política y movimientos sociales en un mundo hegemónico. 1a ed. - Buenos Aires: Consejo Latinoamericano de Ciencias Sociales CLACSO. Pág. 228.

Bobbio, Norberto. 1984. El futuro de la democracia. Política y derecho. México. Fondo de Cultura Económica. Pág. 34.

Bobbio, Norberto. 1985. Por una teoría general de la política. Estado, Gobierno y Sociedad. Fondo de cultura económica. Pág. 43.

Cifuentes P., 2009, María Rocío. La Investigación Sobre Género Y Conflicto Armado. Revista eleuthera. Volumen 3, Enero - Diciembre 2009, págs. 127-164. http://eleuthera.ucaldas.edu.co/downloads/Eleuthera3_5.pdf

Colombia, Corte Constitucional. Sentencia T-406 de 1992 M.P. Ciro Angarita Barón. 
Colombia, Corte Constitucional. Sentencia C-150 de 2015. M.P. Mauricio González Cuervo.

Cortina, Adela. 1998. Sociedad Civil. En: A. Cortina (Ed.), 10 palabras claves en Filosofía Política. Navarra: Verbo Divino. Pág. 8.

Cortina, A. 2010. Las raíces éticas de la democracia. Acto de apertura de la XXVI edición de la Universitat d'Estiu de Gandia (pág. 48). Valencia: Universitat de Valencia. Servei de Publicacions.

Congreso Visible. 2015. Análisis del proyecto de Ley. Recuperado de: http://congresovisible.org/proyectos-de-ley/por-la-cual-se-dictan/6505/\#tab=0 )

Dahl, R. (2004). La Democracia. Posdata: Revista de Reflexión y Análisis Político, 45.

Dewey, J. (1981). My Pedagogic Creed. Chicago: University of Chicago.

Dinkelaker, A. (28 de Junio de 1997). The New Frontier in Democratic Theory and Practice: Organizational Forms that Simultaneously Optimize Autonomy \& Community. Obtenido de http://quadrant4.org/thesis/chapter1b.html

Feminismo en la Conferencia. 1928. Movmientos de mujeres y participación política en Colombia. El tiempo. Pág. 17-2. Recuperado de: http://www.ub.edu/SIMS/pdf/HistoriaGenero/HistoriaGenero-04.pdf

Fraser, Nancy. 1996. “Esferas Públicas, genealogías y órdenes simbólicos “en Iustitia Interrupta, Bogotá: Siglo del Hombre, 1997 pág. 100.

Fraser, Nancy. 1996a, "Redistribución y reconocimiento: hacia una visión integrada de la justicia del género", Revista Internacional de Filosofía Política, Núm. 8, pp. 18-40. 
Feenstra, Ramón A. 2006. "El concepto de sociedad civil En El pensamiento de Michael Walzer". Jornades de Foment de la Investigació. Universitat Jaume I . Recuperado de : http://www.uji.es/bin/publ/edicions/jfi12/21.pdf

Garza, Rafael. 2011. Las teorías de los movimientos sociales y el enfoque multidimensional. Estudios Políticos, México. Pág. 113-116 Recuperado de: http://www.scielo.org.mx/scielo.php?pid=S0185-16162011000100007\&script=sci_arttext

Giugni, Marco. 1998a. Was It Worth the Effort? The Outcomes and Consequences of Social Movements. Annual Review of Sociology 24: 371-393. Recuperado de: http://www.rochelleterman.com/ComparativeExam/sites/default/files/Bibliography\%20and \%20Summaries/Giungi\%201998.pdf

Gobernación del Meta. 2014. Secretaria de la mujer y la equidad de género. Informe: primer año de implementación de política pública de equidad de género para las mujeres del meta 2012-2023. Andrea del pilar verdugo parra.

Habermas, Jürgen, 1998. " La sociedad civil y sus actores, la opinión pública y el poder comunicativo"en Facticidad y Validez". Madrid: Trotta.

Habermas, Jürgen. 1998. " El papel de la jurisdicción y jurisprudencia constitucional en la comprensión liberal, en la comprensión republicana y en la comprensión procedimental de la justicia". Facticidad y Validez, Madrid: Trotta.

Habermas,Jürgen. 1998 . Papel de la sociedad civil. Facticidad y validez. Valladolid. Editorial Trotta. 
Hoyos, Vasquez. Guillermo. 1997. Democracia y derecho. El debate entre Habermas y Rawls. Revista Derecho del Estado No 7, diciembre 1999

Horn, Jessica. 2013. Género y movimientos sociales. Informe General. BridgeDevelopment - Gender. Pág. 25 Recuperado de : http://docs.bridge.ids.ac.uk/vfile/upload/4/document/1402/Género\%20y\%20movimientos\% 20sociales\%20Informe\%20general.pdf

Houtart, François. 2005. Los movimientos sociales en el mundo. Agenda latinoamericana. Año: $2005 . \quad$ Recuperado de: http://www.servicioskoinonia.org/agenda/archivo/obra.php?ncodigo=151

Jolly, Jean- François. Lo público y lo local: gobernancia y políticas públicas. Seminario internacional sobre el Fenómeno Administrativo Público. Mesa Temática Concepción de lo Público y Esquemas de Administración Pública. Escuela Superior de Administración Pública. Bogotá. 2002.

Klandermans \& Tarrow. 1998. Constructivismo social. Mobilization into Social Movements: Synthesizing the European and the American approach. In: Bert Klandermans, Hanspeter Kriesi \& Sidney Tarrow (Eds.) From Structure to Action. Greenwich, Conn. JAI-Press.

Keane, John. 1992. Democracia y sociedad civil. Madrid. Ed. Alianza Universidad de Madrid.

Luna, Lola G. 2006. Mujeres y movimientos sociales. Historia de la mujer en España y América. . Ed. Cátedra. 
Luxemburgo, Rosa. 1984. Problemas de organización de la socialdemocracia rusa. Teoría marxista del partido político, México. Pág. 45.

Mancero, Monica. 2010. Las principales teorías sobre los movimientos sociales. Ciencia, política y poder. Flacso, Ecuador. Pág. 174. Recuperado de: http://www.researchgate.net/profile/Paul_Cisneros/publication/258244449_La_construccin _de_sustentabilidad_ambiental_como_un_problema_de_gobernanza/links/0046352792474 a4446000000.pdf

Martí, Salvador. 2004. Los movimientos sociales en el mundo globalizado._América latina hoy: Revista de ciencias sociales, ISSN 1130-2887, VOL. 36. Págs. 79-100 Recuperado de: http://works.bepress.com/cgi/viewcontent.cgi?article=1033\&context=salvador_martiipuig

Mejía Quintana, Oscar. 2006. "La norma básica como problema iusfilosófico. Tensiones y aporías del positivismo y las apuestas Pospositivistas de superación" en Numas Gil (compilador), Filosofía del Derecho y Filosofía Social_(Memorias Tercer Congreso Nacional), Bogotá D.C.: Grupo Editorial Ibáñez.

Ministerio de Relaciones Exteriores. 2013. Informe Nacional. Cumplimiento del Consenso de Brasilia. Dirección de Asuntos Económicos, Sociales y Ambientales. Recuperado de: http://www.cepal.org/12conferenciamujer/noticias/paginas/7/49917/Informe_COLOMBIA _Vfinal.pdf

Mora Fernandez, Montserrat. 2014. Cátedra UNESCO de Sostenibilidad. Universitat Politécnica de Catalunya. Pág. 5. Recuperado de: http://portalsostenibilidad.upc.edu/detall_01.php?numapartat=8\&id=217

Müller, Pierre. 1989. Les Politiques Publiques. París. PUF. Col: Thémis, Pág. 7-130. 
Naciones Unidas. 2014. Guía Estratégica Empoderamiento Político De Las Mujeres: Marco Para Una Acción Estratégica América Latina Y El Caribe (2014 - 2017). Irune Aguirrezabal Quijera. Asesora de Liderazgo y Participación Política para las Américas y el Caribe. Recuperado de: http://www.unwomen.org/ /media/headquarters/attachments/sections/library/publications/2 014/empoderamiento\%20politico\%20de\%20las\%20mujeres\%20lac\%20201417\%20unwomen.pdf

Naciones Unidas. Comisión Económica para América Latina y el Caribe (CEPAL). 2012. Matriz de Análisis para identificación de políticas justa de igualdad de género. Observatorio de Igualdad de Género de América Latina y el Caribe. Santiago de Chile.

Naciones Unidas. ¿Qué es el enfoque diferencial de género? http://www.hchr.org.co/acnudh/index.php?option=com_content\&view=article\&id=2470:iq ue-es-el-enfoque-diferencial \&catid=76:recursos

Páez, H.; Ocampo, M. Cristina y Villarreal, Norma. 1989. Protagonismo de Mujer. Organización y Liderazgo Femenino en Bogotá, PRODEMOCRACIA, Fundación Friedrich Naumann, Bogotá. Pág. 9. Recuperado de: http://www.eurosur.org/FLACSO/mujeres/colombia/orga-1.htm

Pettit, Philip. (1999) "Democracia y Disputabilidad " en Republicanismo, Barcelona: Paidos.

Programa Estado de la Nación, 2010. Decimosexto Informe Estado de la Nación en Desarrollo Humano Sostenible. San José, Programa Estado de la Nación. Pág. 343. 
http://www.estadonacion.or.cr/files/biblioteca_virtual/015/A_Indice_Inf_15.pdf

Rawls, John. 1996. “La idea de una razón pública“ en El Liberalismo Político. Barcelona: Crítica.

Rosanvallon . Pierre. 2007. La Contrademocracia, Buenos Aires: Manantial. Pág. 284

Rawls, John. 1996. “La idea de un consenso entrecruzado en El Liberalismo Politico”. Barcelona: Crítica.

Santamarina Campos, Beatriz. 2008. Movimientos sociales: una revisión teórica y nuevas aproximaciones. Universidad de Valencia. Pág. 118.

Sartori, G. 1993. ¿Qué es la democracia? México: Tribunal Federal Electoral- Instituto Federal Electoral.

Tribunal Nacional de Mujeres y DESC. 2005. Bogotá. Pág. 163

Villarreal, Norma. 1994. Movimientos de mujeres y participación política en Colombia, 1930-1991. Pág. 67-71. Recuperado en : http://www.ub.edu/SIMS/pdf/HistoriaGenero/HistoriaGenero-04.pdf

Virreira Montaño, Sonia. 2009. Movimientos sociales de mujeres. El Feminismo. Buenos Aires. Pág. 94.

Walzer, Michael. 1998. "La idea de sociedad civil: Una vía de reconstrucción social”. Madrid. Alianza Editorial. Pág. 385. 
Williams, John. Movimientos sociales en África: cambios y perspectivas en el siglo XXI. Documentación social 152. Pág. 113. Recuperado de: http://www.caritas.es/imagesrepository/CapitulosPublicaciones/1003/08\%20$\% 20$ Movimientos\%20sociales\%20en\%20África,cambios\%20y\%20perspectivas\%20en\%20 el\%20siglo\%20XXI.pdf 